\title{
Andrzej Chojnowski
}

Warszawa

\section{Polska po Październiku '56. Przewodnik statystyczny po życiu rodzinnym}

\begin{abstract}
Abstrakt: W Polsce od 1956 r. zachodziły istotne przeobrażenia. Ekipa Władysława Gomułki odeszła od stalinowskiego modelu sprawowania władzy, zrezygnowała z terroru jako metody rządzenia i poszerzyła zakres swobód politycznych. Najtrwalszą konsekwencją tego nowego kursu było porzucenie programu kolektywizacji rolnictwa, co pozwoliło przywrócić na wsi indywidualną własność ziemi. Odzyskał swą podmiotowość Kościół rzymskokatolicki, prześladowany w czasach stalinowskich.
\end{abstract}

Słowa kluczowe: małżeństwo, rodzina, rozwody, dzietność, budownictwo mieszkaniowe, praca kobiet.

Abstract: The events of the Polish October resulted in significant transformations occurring in Poland after 1956. Władysław Gomułka's team departed from the Stalinist model of state, and from terror as the method of ruling, and broadened the scope of political freedoms. The longest-lasting consequence of this new line in politics was the abandonment of the process of collectivisation of agriculture, which made it possible for individual farming to be restored. The Roman Catholic Church, persecuted during the Stalinist period, regained its subjectivity.

Key w or ds: marriage, family, divorce, fertility rate, housing construction, women's labour.

Wielki wiec na pl. Defilad 24 X 1956 r. można porównać z ceremonią intronizacji przez lud Władysława Gomułki. Wprawdzie zebrany wtedy tłum życzył I sekretarzowi KC PZPR „stu lat”, jednak wedle historyków entuzjazm w stosunku do niego dość szybko zaczął gasnąć. Badacze początków rządów ekipy gomułkowskiej pokazuja głównie przebieg procesu, który już w tamtych czasach został nazwany „odchodzeniem od Października”. Opis ten wymaga wszakże wyjścia poza sprawy rozgrywające się wśród elit politycznych i kulturalnych. 
Po 1956 r. Polska podlegała w dalszym ciagu przekształceniom wynikającym z narzucenia systemu jałtańskiego. Zaprowadziły ją one w stronę państwa o nowych granicach, zdominowanego przez jedną ideologię, homogenicznego etnicznie i religijnie, bardziej przemysłowego aniżeli rolniczego.

Pozostawała krajem średniej wielkości, w 1957 r. zamieszkiwało ją ok. 28,5 mln osób ${ }^{1}$, wśród których przeważali mieszkańcy wsi, ale była to przewaga mniejsza niż 7 lat wcześniej. Proporcje między kobietami a mężczyznami utrzymywały się natomiast na zbliżonym poziomie ${ }^{2}$.

W 1957 r. przyszło na świat 782 tys. noworodków (przyrost naturalny wyniósł 513 tys.). Liczba ta mogła być znacznie większa, jednak w efekcie uchwalonej w kwietniu 1956 r. ustawy o dopuszczalności przerywania ciąży, w 1957 r. w szpitalach i ambulatoriach przeprowadzono ponad 121 tys. tego rodzaju zabiegów ${ }^{3}$. Było ich bez wątpienia więcej, tyle że ówczesna statystyka nie ujmowała przypadków aborcji poza placówkami służby zdrowia, jak też stosowanych w domach metod „chininowo-kapielowych”4.

Noworodek męski miał przed sobą przeciętnie 61,8 lat życia, natomiast żeński - 67,8. Mieszkaniec Polski żył w końcu lat pięćdziesiątych równie długo co statystyczny Amerykanin, o 4-5 lat krócej niż Duńczyk, Norweg i Szwed, o 6 lat dłużej niż Portugalczyk. W porównaniu z czasami II Rzeczypospolitej średnia długość ludzkiego życia wzrosła o 13 lat w wypadku mężczyzn i o 16 lat w wypadku kobiet. Stopniowo ustępowały w tym względzie różnice pomiędzy miastem a wsia ${ }^{5}$.

Sukcesem lat pięćdziesiątych był spadek umieralności noworodków i niemowląt ${ }^{6}$, ale i tak Polska zajmowała pod tym względem czwarte miejsce od końca w Europie, a za nami pozostały jedynie Portugalia, Jugosławia i Albania.

${ }^{1}$ W porównaniu z 1950 r., kiedy to przeprowadzono Narodowy Spis Powszechny, liczba ludności wzrosła o 11\%. Wszystkie dane, o ile nie wskazano innego źródła, pochodzą z Roczników statystycznych oraz Małych roczników statystycznych, publikowanych przez GUS.

${ }^{2}$ W 1950 r. mieszkańcy wsi stanowili 63\% ludności, w 1957 r. - 54,5\%; w 1950 r. kobiety to $52,3 \%$ populacji, w 1957 r. $-51,8 \%$.

${ }^{3}$ A. Czajkowska, O dopuszczalności przerywania ciaży. Ustawa z dnia 27 kwietnia 1956 r. $i$ towarzyszace jej dyskusje, w: P. Barański i in., Kłopoty z seksem $w$ PRL. Rodzenie nie catkiem po ludzku, aborcja, choroby, odmienności, red. i wstęp M. Kula, Warszawa 2012, s. 180 . W 1960 r. doszło do 224 tys. terminacji ciąży, w tym 4 tys. zabiegów ze wskazań lekarskich, 146 tys. ze wskazań społecznych, na resztę składały się przypadki poronień o innym podłożu. Kobieta w Polsce. Dane statystyczne, Warszawa 1968, s. 160-161.

${ }^{4}$ Jaka jesteś, rodzino?, wybór i oprac. M. Parzyńska, I. Tarłowska, Warszawa 1963, s. 25. Książka zawierała wybór prac nagrodzonych w konkursie „Życia Warszawy” z 1962 r. przez jury pod przewodnictwem Antoniny Kłoskowskiej.

5 Porównano lata 1931/1932 oraz 1955/1956. Mężczyzna w mieście żył przeciętnie 62,2 lat, na wsi - 61,6 lat; kobieta w mieście - 68,7 lat, na wsi - 67 lat.

${ }^{6}$ Umieralność $w$ latach 1950-1957. Przyczynek do analizy, oprac. J. Blaźnik, J. Holzer, Warszawa 1961, s. IV; J. Holzer, Prognoza demograficzna Polski na lata 1960-1975 wedtug województw, Warszawa 1959, s. 21. W 1950 r. zmarło ok. 82 tys. niemowląt (poniżej 1. roku życia), w 1960 r. - ok. 37,5 tys. 
Polska w okresie gomułkowskim powiększała się pod względem demograficznym. Jak wiadomo, ówczesne państwo brało na siebie, ze względów doktrynalnych, odpowiedzialność za zapewnienie ludności mieszkań, miejsc w przedszkolach, szkołach i szpitalach, możliwości pracy i wypoczynku itp. Centralny planista miał także określić przewidywany zakres potrzeb dotyczacych usług, zdolności komunikacji do przewożenia rosnącej liczby osób i wielu podobnych kwestii. Lęk, czy uda się to wszystko uczynić, stanowił ważna determinantę postępowania rządzących, a także prosystemowych dziennikarzy i ekspertów. Stąd niektórzy publicyści postulowali np. zniesienie wszelkich ograniczeń (poza zdrowotnymi) przerywania ciąży, zwracając uwagę na niewykonalność programu budowy szkół dla powiększającej się armii dzieci ${ }^{7}$.

Jeśli spojrzeć wszakże w dłuższej perspektywie, sytuacja była bardziej złożona. To prawda, że w latach pięćdziesiątych liczba ludności wyraźnie rosła, także dzięki spadkowi śmiertelności niemowląt. Dzieci w liczbach bezwzględnych przybywało, ale wskaźnik urodzeń się zmniejszał ${ }^{8}$. Generalizujące prognozy, zapowiadające powolne wyludnianie się Polski, znajdowały potwierdzenie w badaniach o charakterze szczegółowym.

Instytut Gospodarki Mieszkaniowej monitorował np. w latach sześćdziesiątych losy kilkuset małżeństw w Warszawie i we Wrocławiu. Ankieta objęto nowożeńców, którzy wzięli ślub w 1963 r., mając nie więcej niż 30 lat, a w związek małżeński wstępowali po raz pierwszy ${ }^{9}$. Po dwóch latach $49 \%$ tych małżeństw w stolicy nadal nie miało dzieci, a 49\% doczekało się jednego potomka. W 1969 r. 16\% małżonków było wciąż bezdzietne, $68 \%$ posiadało jedno dziecko, dwójkę zaś - $15 \%{ }^{10}$. Rodzina wielodzietna stopniowo zanikała na rzecz rodziny posiadajacej jedno lub dwoje dzieci ${ }^{11}$.

Demografowie, szukając przyczyn tej tendencji, analizuja rozmaite dane statystyczne, np. zmiany w strukturze wieku rozrodczego kobiet ${ }^{12}$. Historycy

${ }^{7}$ M. Maneli, Niedonoszone przepisy, „Prawo i Życie” 1959, nr 12. Autor zwracał m.in. uwagę na wysokie koszta budowy nowych szkół.

${ }^{8}$ Wskaźnik urodzeń żywych na 100 kobiet w wieku 15-49 lat spadł w latach 1955-1966 z 11 do 7. Było to głównie spowodowane zmniejszeniem narodzin wśród kobiet powyżej 29. roku życia. Kobieta $w$ Polsce..., s. XVI, 7.

9 Z. Barszczewska, T. Guzek, Z. Pindor, Zmiany w sytuacji mieszkaniowej młodych matżeństw $w$ Warszawie $i$ Wrocławiu ( $w$ świetle powtórnych badań IGM w 1969 r.), Warszawa 1971, s. 6. W całym kraju w 1963 r. zawarto 219,8 tys. małżeństw.

${ }^{10}$ Ibidem, s. 28. We Wrocławiu w badanej grupie małżeństwa bezdzietne stanowiły w $1965 \mathrm{r}$. 30\%, w 1969 r. - 8,8\%. Rodzin z jednym dzieckiem było w 1969 r. 60,6\%. Ibidem, s. 41.

${ }^{11}$ Kobieta $w$ Polsce..., s. XIX. Ankietowani w latach sześćdziesiątych studenci warszawskiej AWF deklarowali, że chcieliby mieć maksimum dwójkę dzieci. Dziecko powinno się pojawić po „dwóch-czterech latach małżeństwa”, ,ale tylko w tym wypadku, gdy rodzice sa w stanie zapewnić mu byt i należyte wychowanie”. B. Łobodzińska, Młodość, miłość matżeństwo, Warszawa 1975, s. 40. Zob. też: eadem, Rodzina $w$ Polsce, Warszawa 1974, s. 43-44.

12 O dynamice urodzeń decydowały przede wszystkim kobiety w wieku 20-34 lat. Wskaźnik urodzeń żywych na 100 kobiet w tej kategorii wynosił w 1955 r. 20,8, w 1965 - 18,5. Kobieta $w$ Polsce..., s. XVI, 7. 
i socjologowie zwracają uwagę na ekonomiczne i społeczne podłoże decyzji małżonków. Innymi słowy, chodzi o opis różnorakich aspektów funkcjonowania rodziny ${ }^{13}$.

W 1957 r. urzędy stanu cywilnego odwiedziło 256,7 tys. par, co nie odbiegało od stanu z lat poprzednich. W pierwszej połowie lat sześćdziesiątych nastapił spadek, od 1966 r. liczba małżeństw znów rosła jako owoc powojennego wyżu demograficznego.

Wprawdzie w potocznym wyobrażeniu zawarcie ślubu nie wymaga uzasadnienia, jednak nauki społeczne staraja się poznać indywidualne motywy takiego kroku, jak też odtworzyć wyobrażenia na temat modelu idealnego małżeństwa. Tak też było i w PRL, przy czym polska socjologia w latach sześćdziesiątych dopiero odbudowywała się z zapaści okresu stalinowskiego. Ówczesne badania miały charakter fragmentaryczny, tylko niekiedy prowadzono je $\mathrm{z}$ wykorzystaniem tzw. próby reprezentatywnej. Ułamkowość zgromadzonego materiału utrudniała podjęcie dialogu z nauka zachodnia, jak też przeniesienie na grunt polski stworzonych za granica teorii interpretacyjnych. Polskie publikacje miały ponadto podtekst ideologiczny, socjologowie starali się bowiem wykazać, że w nowej rzeczywistości ustrojowej młodzi ludzie przestali już być więźniami pochodzących z przeszłości konwenansów obyczajowych, różnic społecznych czy przymusu ekonomicznego ${ }^{14}$. Wszystko to każe traktować ówczesne osiagnięcia socjologii z ostrożnością, ale jednocześnie nie można ich zastapić innymi ustaleniami.

Prowadzone w latach sześćdziesiątych badania objęły regionalne społeczności, grupy społeczno-zawodowe ${ }^{15}$ i środowiska młodzieży ${ }^{16}$. Potwierdzały one, co można było przewidzieć, że choć ankietowani wiązali zawarcie małżeństwa z miłością to jednocześnie widzieli w nim instytucję ułatwiająca osiagnięcie sukcesu materialnego, zapewniająca wzajemną pomoc i opiekę, a także posiadanie i wychowywanie dzieci ${ }^{17}$.

${ }^{13}$ Liczebność kategorii tzw. dzieci pozamałżeńskich nie wpływała wówczas znacząco na liczbę urodzeń. Na podstawie badań można uznać, że większość takich urodzeń nie wynikała ze świadomej decyzji matki, lecz była skutkiem przypadku, lekkomyślności, nieznajomości metod antykoncepcji itp. B. Łobodzińska, Rodzina w Polsce..., s. 157-58.

${ }^{14}$ Eadem, Niektóre problemy analizy instytucji matżeństwa $w$ Polsce. Determinanty zawierania i realizacji matżeństwa, „Studia Socjologiczne” 1966, nr 1 (2), s. 190.

${ }_{15}$ Przykładowo: A. Kłoskowska, Badania modelu rodziny $w$ tódzkim środowisku robotniczym, „Przegląd Socjologiczny” 1960, nr 1; W. Mrozek, Z badań nad rodzinq górnicza, „Górnoślaskie Studia Socjologiczne" 1963, nr 1; D. Markowska, Rodzina wiejska w rejonie Płocka, „Zeszyty Badań Rejonów Uprzemysławianych” 1963, nr 6.

${ }^{16}$ Najpoważniejszy walor informacyjny miała przeprowadzona w 1965 r. ankieta Ośrodka Badania Opinii Publicznej przy Polskim Radio i Telewizji. Objęto nią reprezentację dorosłej ludności miast (powyżej 18. roku życia). B. Łobodzińska, Poglady na funkcje instytucji matżeństwa, „Studia Socjologiczne” 1969, nr 4, s. 104.

17 Eadem, Poglady..., s. 105. 
Ciekawe wnioski płynęły z ankiety „Sztandaru Młodych”, pt. Życie we dwoje $(1963)^{18}$. Redakcja pytała czytelników nie tylko o powody skłaniajace do zawarcia ślubu, ale prosiła też o określenie pożądanych cech partnera, dając wybór między 16 kategoriami, takimi jak inteligencja, uroda, wierność, zaradność, opiekuńczość, wykształcenie, umiejętność zarabiania i in. $\mathrm{Z}$ odpowiedzi wynikało, że kobiety oczekują od przyszłych mężów wierności, zaradności życiowej, inteligencji, poczucia humoru i opiekuńczości, mężczyźni zaś chcieliby żony wiernej, inteligentnej, zaradnej, gospodarnej i schludnej. Najmniej popularnymi wartościami okazały się w odniesieniu do męża religijność, elegancja, uroda i domatorstwo, a do żony - umiejętność zarabiania pieniędzy, religijność i domatorstwo ${ }^{19}$.

W wynikach tej ankiety uwage zwracało zepchnięcie na dalszy plan umiejętności zarabiania, przy równocześnie wysokich notowaniach zaradności. Pozostawało to $\mathrm{w}$ zgodzie $\mathrm{z}$ realiami tamtego czasu, kiedy to posiadanie pieniędzy nie rozwiązywało samo w sobie życiowych problemów. Dlatego też w społecznych odczuciach wzorem do naśladowania była nie tylko osoba na dobrze płatnej posadzie, lecz także bohater ludowej anegdoty (trudno orzec, czy prawdziwej), który zobaczywszy, że ktoś pozostawił przed klatką schodowa zakupiona gdzieś cudem wannę, zdołał w ciagu kwadransa zorganizować transport, znaleźć nabywcę i zainkasować od niego gotówkę za skradziony sasiadowi produkt. W terminologii naukowej zaradnością nazywano umiejętność dostosowania się do sytuacji... ${ }^{20}$

Wypowiadający się na te tematy widzieli w wynikach badań potwierdzenie różnicy między męskim i żeńskim, jak też miejskim i wiejskim modelem małżeństwa ${ }^{21}$. Kobiety podkreślały znaczenie więzi uczuciowych, wierzyły, że w małżeństwie odnajdą miłość, oparcie, zrozumienie ${ }^{22}$. Mężczyźni oczekiwali od małżeństwa gwarancji seksualnej wyłączności partnerki, przede wszystkim zaś chcieli realizowania w związku zasady prymatu męża. W odczuciach męskich mieszkańców wsi dobra żona to kobieta gospodarna, pracowita, łagodna, szanująca męża, troskliwa wobec dzieci. Mężczyźni w miastach nie negowali znaczenia tych cech, ale oczekiwali ponadto, że żona będzie umilać życie mężowi, dzięki czemu jego egzystencja nabierze większej atrakcyjności ${ }^{23}$.

18 Ankieta nie miała cech reprezentatywności, wzięło w niej udział 719 osób, w większości pracowników umysłowych. Eadem, Niektóre problemy..., s. 198.

19 Ibidem, s. 206.

${ }^{20}$ Ibidem, s. 207.

${ }^{21} \mathrm{~W}$ literaturze socjologicznej klasyfikacja ta była bardzo rozbudowana. Wyróżniano tam modele: tradycyjnej rodziny chłopskiej, współczesnej rodziny rolniczej, rodziny chłoporobotniczej, wiejskiej rodziny robotniczej, rodziny miejskiej pochodzenia wiejskiego, rodziny robotniczej, rodziny urzędniczej i rodziny inteligenckiej. B. Łobodzińska, Rodzina w Polsce..., s. 17 i n.

${ }^{22}$ Pamiętajmy, że mowa jest tu indywidualnych wyobrażeniach i deklaracjach intencji.

${ }^{23}$ B. Łobodzińska, Niektóre problemy..., s. 205-206. 
Przy tworzeniu związku zachowały znaczenie aspekty społeczne i środowiskowe. Tam, gdzie pracowali obydwoje małżonkowie, $60 \%$ mężczyzn wykonujących prace fizycznie (poza rolnictwem) związanych było z kobietami pracującymi fizycznie. Połowa żon pracujących umysłowo miała za mężów robotników, natomiast tylko 20\% małżonków - za żony robotnice. Wywodzący się ze wsi w $60 \%$ zawierali małżeństwa z partnerami o identycznym pochodzeniu, taki sam wskaźnik charakteryzował wybory partnera przez osoby pochodzące $\mathrm{z}$ dużych miast ${ }^{24}$.

W porównaniu z „zamierzchłymi” czasami traciła na znaczeniu tradycyjnie rozumiana instytucja posagu. Miejsce bielizny pościelowej czy zastawy stołowej zajmowały cechy osobowościowe przyszłego współmałżonka oraz umiejętności przydatne w realizacji planów życiowych. W przeanalizowanych przez socjologów ogłoszeniach matrymonialnych posiadanie zawodu deklarowało 48\% kobiet i 73\% mężczyzn, traktując to jako swój główny atut ${ }^{25}$.

Szukając różnic między modelem tradycyjnym (przedwojennym) a modelem nowoczesnym (powojennym), zwracano uwagę na poglądy na temat trwałości małżeństwa. Pisząca często na te tematy autorka nadawała znaczenia emocjom, jakie towarzyszyły niektórym wątkom powieści radiowej $W$ Jezioranach. Jedna z bohaterek słuchowiska rozstaje się z mężem-alkoholikiem i układa sobie życie z innym mężczyzną (rzecz działa się w 1960 r.). Gdy nowy związek zaczyna się cementować, pojawia się mąż, już po kuracji, nalegając na odbudowanie małżeństwa. Pytanie, co powinna uczynić Wanda, podzieliło słuchaczy - w $80 \%$ były to kobiety z małych miasteczek i wsi. Większość odradzała bohaterce powrót do przeszłości, argumentując, że „pijak pozostanie pijakiem", tylko $21 \%$ namawiało ja do wybaczenia mężowi ${ }^{26}$. $\mathrm{Na}$ tej podstawie można było wnioskować, że w świadomości mieszkańców „dalekiej prowincji” zachodzą zmiany, a utrzymywanie małżeństwa za wszelką cenę powoli przestaje być wartością ${ }^{27}$. Tyle że listów, które napłynęły do redakcji w tej sprawie, było zaledwie 120 , statystyki zaś pokazywały, że rozwody na wsi pozostaja zjawiskiem rzadkim ${ }^{28}$.

Niezależnie od fragmentaryczności materiału zgromadzonego przez socjologów, redakcje czasopism i reportażystów można było na jego podstawie odtworzyć katalog problemów, które nurtowały wstępujacych na małżeńska ścieżkę. Ich zwierzenia brzmiały niekiedy bardzo dramatycznie. Powtarzał się w nich wątek braku psychicznego porozumienia małżonków, tragicznie złych stosunków z rodzicami, braku satysfakcji z życia seksualnego (przede wszystkim u dziewcząt), jak też nieznajomości mechanizmów tej sfery

\footnotetext{
${ }^{24}$ Eadem, Rodzina $w$ Polsce..., s. 172.

${ }_{25}$ Eadem, Manowce matżeństwa i rodziny. Szkice obyczajowe, Warszawa 1963, s. 114.

${ }^{26}$ Eadem, Młodość, miłość..., s. 103-107.

${ }^{27}$ Ibidem, s. 112-113.

${ }^{28}$ Kobieta $w$ Polsce..., s. XIX. O rozwodach zob. dalej.
} 
funkcjonowania ludzkiego organizmu ${ }^{29}$. Stąd nie należał do odosobnionych casus dziewczyny, która „zaszła w ciążę po pierwszym zbliżeniu” ${ }^{30}$. Skala takich przypadków niemożliwa jest do statystycznego oszacowania, ale przypuszcza się np., że w końcu lat sześćdziesiątych odsetek kobiet, które brały ślub, będąc w odmiennym stanie, wynosił $25 \%{ }^{31}$.

Przedstawiajac te kwestie, należy mieć na uwadze wiek zawierających małżeństwa. I tak wśród nowo poślubionych w $1957 \mathrm{r}$. dominowały kobiety w przedziale wieku 20-24 lat (46\%) i poniżej 19. roku życia (23,9\%), a także mężczyźni w wieku 20-24 lat (41\%) i 25-29 lat (34,7\%) ${ }^{32}$. W 1966 r. trzy czwarte ogólnej liczby panien młodych stanowiły kobiety poniżej 25 . roku życia, gdy zaś chodzi o mężczyzn - niemal połowa. Małżeństwa mężczyzn powyżej 40. roku życia z kobietami poniżej 30. roku życia należały do rzadkości ${ }^{33}$. W tamtejszych realiach kulturowych niezamężna dziewczyna, która miała więcej niż 23 lata, miała duże szanse otrzymać miano „starej panny” ${ }^{34}$.

Małżeństwo dawało przepustkę do dorosłości, okazję do wyemancypowania się spod władzy rodziców, stanowiło więc bardziej drogę do celu (stabilizacji w społeczności dorosłych) niż wartość samą w sobie. Młodzi ludzie autonomizowali się dzięki temu, że ślub był decyzja, na którą rodzice nie mieli wpływu. „Gdy skończyłam 18 lat, pobraliśmy się - pisała 23-letnia dziewczyna - Nie zastanawiałem się nad tym, co to jest małżeństwo. Chciałam jak najprędzej wyrwać się z domu, od ojca i być razem z Robertem" ${ }^{35}$. Inna dwudziestolatka przyznawała:

${ }^{29}$ Spośród pacjentek II Kliniki Ginekologicznej Akademii Medycznej w Poznaniu, ankietowanych w latach 1959-1963, satysfakcję z seksu (powyżej 5 punktów w skali od 1 do 10) deklarowało $43 \%$ kobiet. H. Malewska, Kulturowe i psychospołeczne determinanty życia seksualnego, Warszawa 1967, s. 83.

${ }^{30}$ Młodzi po ślubie, wybór i oprac. M. Parzyńska, J. Horodecka, Warszawa 1966, s. 22. (Książka zawierała wybór wypowiedzi w ankiecie rozpisanej przez „Życie Warszawy”).

31 B. Łobodzińska, Rodzina w Polsce..., s. 159. W Polsce ok. 62\% kobiet rozpoczynało życie seksualne przed ślubem, w większości z przyszłymi mężami. Wśród urodzonych w latach 1925-1931 4\% uprawiało seks przed 16. rokiem życia, 27\% - w wieku 16-18 lat, 44\% w wieku 19-22 lat. Eadem, Młodość, miłość..., s. 242. Wskaźnik zachorowań na choroby weneryczne na 10 tys. ludności wzrósł z 11,8 w 1960 r. do 16,9 w 1965 r. Eadem, Rodzina $w$ Polsce..., s. 115.

${ }^{32}$ Dla porównania - w 2013 r. średnia wieku kawalerów, zawierających małżeństwo po raz pierwszy, wynosiła w Polsce 28 lat, a panien - 26 lat.

${ }^{33}$ Kobieta $w$ Polsce..., s. XVII.

${ }^{34}$ B. Łobodzińska, Młodość, miłość..., s. 85. Mężczyźni brali ślub przed odbyciem służby wojskowej, co np. w wypadku ludności wiejskiej i proletariackiej w czasach II RP nie mieściło się w aprobowanej normie postępowania. Skracał się czas narzeczeństwa, a reporterzy odnotowywali w połowie lat pięćdziesiątych przypadki małżeństw ludzi praktycznie nieznajacych się, zawartych dla żartu, w ramach realizacji towarzyskiego zakładu itp. W odróżnieniu od losów bohaterów filmu Rozwodów nie będzie (reż. J.S. Stawiński, 1963) związki te rozpadały się bardzo szybko. J. Lovell, Sa takie dzielnice. Reportaże, Warszawa 1956, s. 132 i n.

${ }^{35}$ B. Łobodzińska, Młodość, miłość..., s. 123. 
że na nic [...] zdały się perswazje rodziców, którzy usiłowali nas za wszelką cenę przekonać, że jesteśmy jeszcze zbyt młodzi, że nie znamy życia i że nie jest ono tak łatwe i proste, jak nam się to wydaje. Wszystkich przyjaciół, którzy byli tegoż zdania, uważaliśmy za wrogów, za ludzi, którzy nie pragną naszego szczęścia ${ }^{36}$.

Sygnalizowany w tych wypowiedziach konflikt pokoleniowy znajdował potwierdzenie $\mathrm{w}$ relacjach, w których nastolatkowie zarzucali rodzicom, że poza psychiczna presją łatwo też stosują bicie, by wyperswadować swym pociechom młodzieńcze „fanaberie”. Toteż ślub wydawał się wybawieniem, ale okoliczności podejmowania takiej decyzji oraz późniejsze rozczarowanie „życiem w związku” sygnalizowały skażenie myślenia młodzieży infantylizmem. Dlatego od stycznia 1965 r. podniesiono ustawowy wiek zawierania małżeństwa dla mężczyzn z 18 do 21 lat.

Ślub nie oznaczał jednak wcale uwolnienia od problemów, a nawet wręcz przeciwnie. Po jego zawarciu nowożeńcy pragnęli z zasady prowadzić życie pod wspólnym dachem. W PRL nie było to jednak proste i można złośliwie stwierdzić, że Polska gomułkowska odgrywała niezamierzenie rolę prekursorki popularnej dziś w niektórych krajach formy relacji międzyludzkich nazywanej LAT (Living Apart Together). Wedle wspomnianych wyżej badań Instytutu Gospodarki Mieszkaniowej (zob. przypis 9) w Warszawie w 1963 r. tylko 4\% młodych par dysponowało mieszkaniem samodzielnie użytkowanym, we Wrocławiu - 10\%, natomiast aż 33,7\% nowożeńców warszawskich i $26 \%$ wrocławskich żyło w lokalowej rozłące. Spośród tych, którym udawało się tego uniknąć, 79\% par w Warszawie i $65,7 \%$ we Wrocławiu mieszkało z rodzicami, a $14,6 \% \mathrm{w}$ Warszawie i $25,7 \%$ we Wrocławiu posiadało status sublokatorów ${ }^{37}$.

Gdzie się mamy podziać? - to pytanie było dla młodych małżeństw jednym z najważniejszych.

Początkowo mieszkaliśmy oddzielnie w dwóch różnych akademikach - relacjonowała młoda studentka - położonych na przeciwległych krańcach Warszawy. To oddzielne mieszkanie z biegiem czasu zaczęło nas męczyć. Po wielu staraniach znaleźliśmy maleńki pokoik za 400 zł miesięcznie, co na stosunki warszawskie było niewiele, ale nasz budżet studencki bardzo nadwyrężało ${ }^{38}$.

Kolejna uważała się za obdarowaną przez los, gdy „po roku, chyba cudem, udało nam się znaleźć w nowym budownictwie pokój 12 metrów kwadratowych, za który [...] płaciliśmy 200 zł miesięcznie. Byliśmy jednak uszczęśliwieni; pierwszy ugotowany w domu obiad smakował wspaniale" ${ }^{39}$. Ale inna, po

\footnotetext{
${ }^{36}$ Młodzi po ślubie..., s. 44.

37 Z. Barszczewska, T. Guzek, Z. Pindor, op. cit., s. 15, 49. Aż 36\% małżeństw warszawskich mieszkających „u kogoś” nie posiadało odrębnego pokoju.

${ }^{38}$ Młodzi po ślubie..., s. 44.

${ }^{39}$ Ibidem, s. 22.
} 
zajściu w ciążę, wpadła „w rozpacz bez granic”, bo bytowała wraz z mężem „u rodziców [...] w mieszkanku o 15 metrach kwadratowych” ${ }^{40}$.

Po Październiku '56 budownictwo mieszkaniowe funkcjonowało początkowo wedle zasad stworzonych w okresie stalinowskim ${ }^{41}$. Państwo występowało w roli inwestora, wykonawcy robót, właściciela i administratora nowo powstajacych osiedli, przydzielajacc lokale wedle własnego uznania, w pierwszej kolejności osobom zasłużonym dla systemu ${ }^{42}$. Owa omnipotencja nie była jednak całkowita. W latach 1950-1957 z funduszy państwowych pokryto koszta powstania $65,7 \%$ mieszkań, a ze środków prywatnych - ponad $33 \%{ }^{43}$.

Pierwsze trzy lata planu sześcioletniego przyniosły spadek liczby mieszkań oddawanych corocznie do użytku, natomiast w 1957 r. wybudowano ich o 25\% więcej aniżeli w roku poprzednim. Na przełomie 1957/1958 r. zasady polityki mieszkaniowej zostały strukturalnie zmienione, a intencja władz popaździernikowych stała się likwidacja systemu bezpłatnego przydzielania mieszkań przez państwo, jak też odejście od pokrywania z budżetu całości kosztów eksploatacji i remontów ${ }^{44}$. Na taki wybór wpłynęły realia. Przykładowo w Bielsku-Białej w 1957 r. w Wydziale Kwaterunkowym Rady Narodowej złożono 10 tys. podań o przydział lokalu, po weryfikacji odrzucono co prawda 5 tys., lecz w tymże roku zbudowano w systemie ZOR (Zakładowe Osiedla Robotnicze) tylko 473 izby, podczas gdy w mieście zawarto 873 małżeństwa i urodziło się 2694 dzieci $^{45}$. Wysoce ograniczone możliwości ekonomiczne kraju nie dawały o sobie zapomnieć, toteż podtrzymywanie wśród ludności

${ }^{40}$ Ibidem, s. 32.

${ }^{41}$ D. Jarosz, Mieszkanie się należy... Studium z peerelowskich praktyk społecznych, Warszawa 2010, s. 28 i n.

${ }^{42}$ Ibidem, s. 39. Państwo pokrywało też koszta utrzymania nowo wybudowanych mieszkań, jako że wysokość czynszów została ustalona na bardzo niskim poziomie, który nie wystarczał ani na eksploatację, ani na konserwację i remonty. Osobną kwestią jest administrowanie przez wydziały kwaterunkowe rad narodowych lokalami w ocalałych po wojnie budynkach komunalnych, spółdzielczych i prywatnych. Uchwały Rady Ministrów z lat 1951-1952 wyznaczały „normę zaludnienia powierzchni użytkowej mieszkania”, a odpowiednie instancje administracyjne uzyskały możliwość dokwaterowywania lokatorów do mieszkań, w których wykryto powierzchnię „ponadnormatywną. Ibidem, s. 43-45. Normalna praktyką było przekazywanie mieszkań spółdzielczych do użytku pracownikom różnych urzędów i przedsiębiorstw państwowych kosztem prawowitych właścicieli. W niektórych spółdzielniach budynki były w 70-80\% zajmowane przez nasłanych przez kwaterunek lokatorów.

${ }^{43}$ Ta druga sfera stanowiła pole aktywności głównie ludności rolniczej, dzięki której wytworzono $77 \%$ mieszkań tej kategorii. Należy jednocześnie mieć świadomość, że od czasów „odwilży” wśród indywidualnych inwestorów pojawili się też np. pracownicy aparatu partyjno-państwowego różnych szczebli, którzy zapewniali sobie przydziały materiałów budowlanych, kosztem chłopów, jak również kadra techniczna i zarządzająca dużych przedsiębiorstw. J. Hibner, Niedaleko Warszawy, „Prawo i Życie” 1957, nr 18; M. Leja, Widokówki ślaskie, „Walka Młodych” 1957, nr 23.

${ }^{44}$ D. Jarosz, op. cit., s. 46.

${ }^{45}$ M. Górski, Bielsko-Biała 1958, „Polityka” 1958, nr 13. 
przekonania, że należy jej się od państwa mieszkanie, musiałoby doprowadzić do społecznej katastrofy.

Budownictwo finansowane w całości przez państwo pozostało w domenie organizacyjnej rad narodowych i miało zapewnić mieszkania obywatelom o miesięcznym dochodzie znacząco niższym niż przeciętny ${ }^{46}$, a także osobom zamieszkującym strychy, piwnice lub też miejsca nienadające się do przebywania tam w zimie lub całkowicie „niemieszkalne [sic!]”47.

Inną ścieżką stało się tzw. budownictwo przyzakładowe rozwijane w kilku formach organizacyjnych. Od pretendujących do otrzymania mieszkania oczekiwano wniesienia tzw. wkładu własnego (ok. 15\% wartości lokalu), pozostałe koszta zamierzano pokrywać z kredytów bankowych (de facto państwowych), a w dłuższej perspektywie - także z zakładowych funduszy budownictwa mieszkaniowego ${ }^{48}$.

Pozostali obywatele zmuszeni byli wkroczyć na „spółdzielczą drogę do mieszkania" ${ }^{49}$. Był to taki sam eufemizm, jak nazywanie gehenny pasażerów niemożliwie zatłoczonych w okresie wakacyjnym pociagów „,szczytem wyjazdowym". Wkład własny członków spółdzielni wyznaczano na 10-15\% wartości mieszkania, reszta miała zostać pokryta z bankowych kredytów zwrotnych. W zamyśle władz leżało też „urealnienie” wysokości komornego, co jednak postępowało z dużymi oporami. W $1965 \mathrm{r}$. w spółdzielniach zmieniono zasady naliczania czynszów, tak aby pokrywały one w pełni koszta eksploatacji. W rzeczywistości nowe czynsze wystarczały na dokonanie drobnych napraw, pozostawały jednak nadal zbyt niskie, żeby przeprowadzać kapitalne remonty ${ }^{50}$.

Aby zmniejszyć rosnaccą kolejkę starających się o mieszkanie, w 1965 r. wprowadzono instytucję kandydata na członka spółdzielni. Członkiem pełnoprawnym można było zostać dopiero po wniesieniu określonego zasobu lub zaliczki na wkład budowlany. Takie osoby podpisywały ze spółdzielnia umowę, która rygorystycznie określała ich obowiązki, natomiast władze

46 Średnie wynagrodzenie miesięczne na osobę wynosiło w 1950 r. 551 zł, w 1958 r. - 1348 zł, a w 1965 r. - 1867 zł.

${ }^{47} \mathrm{~W}$ grupie starających się o mieszkanie pracowników Fabryki Samochodów Osobowych w Warszawie odsetek osób żyjących w suterynach, na poddaszach, w budynkach nienadających się do użytkowania w zimie bądź w pomieszczeniach niemieszkalnych wynosił $14 \%$ (dane z 1959 r.). W. Czeczerda, Warunki i życzenia mieszkaniowe różnych grup ludności. Metoda $i$ wyniki badań ankietowych, Warszawa 1964, s. 25. Wedle danych uzyskanych w Wydziale do Spraw Lokalowych Stołecznej Rady Narodowej we wrześniu 1957 r. w Warszawie znajdowało się 607 zagrożonych zawaleniem się budynków o prawie 3 tys. izb, w których mieszkało ok. 8 tys. osób. B. Seidler, Warszawa bez retuszu. Fakty i liczby, „Nowa Kultura” 1957, nr 39.

${ }^{48}$ D. Jarosz, op. cit., s. 46.

${ }^{49} \mathrm{~W}$ praktyce do spółdzielni przystępowały także i osoby o dochodach niższych od średniego wynagrodzenia. T. Żarski, Budownictwo mieszkaniowe $w$ Polsce 1950-1965, Warszawa 1966, s. 56.

50 Ibidem, s. 96-97. 
spółdzielni mówiły o swoich powinnościach dość ogólnie, używając formuły: „przewidywany przydział mieszkania nastapi około roku...” Zakładano, że stanie się to po ok. 5 latach, co okazało się utopia ${ }^{51}$.

Nowa spółdzielczość mieszkaniowa rozwijała się opieszale ${ }^{52}$. W latach 1961-1965 oddano w Polsce do użytku 754 tys. mieszkań (z czego 74,2\% w miastach), przy zdecydowanej przewadze budownictwa państwowego $(52,4 \%)$. Udział spółdzielni wyniósł $16,4 \%$, a inwestorów indywidualnych $-31,2 \%^{53}$.

Powołując do życia model spółdzielczy, władze pragnęły przerzucić część kosztów budownictwa na barki obywateli. W praktyce tworzono nowa fikcję ekonomiczna, jako że spółdzielczość była od początku w dużej mierze „utrzymanką" państwa. W 1958 r. zainteresowani pokryli tylko 35\% nakładów na spółdzielczość, a w 1964 r. odsetek wkładu własnego spółdzielców spadł do $16 \%{ }^{54}$.

Od 1957 r. nowych izb w liczbach bezwzględnych wprawdzie przybywało, ale i tak Polska na początku lat sześćdziesiątych zajmowała w bloku sowieckim ostatnie miejsce, gdy chodzi o liczbę oddawanych do użytku mieszkań w przeliczeniu na 1000 osób $^{55}$. W warstwie propagandowej traktowano zapewnienie obywatelom własnego „dachu nad głową" jako zadanie priorytetowe, w praktyce odsetek nakładów na budownictwo w puli całości inwestycji zmniejszył się z 20\% w 1959 r. do $15 \% \mathrm{w} 1965$ r. ${ }^{56}$ Wspomniany wyżej wzrost liczebny osiagano metoda tzw. budownictwa oszczędnego, zapowiedzianego w trakcie V Plenum KC PZPR w czerwcu 1960 r., a realizowanego od następnego roku ${ }^{57}$.

${ }^{51}$ W 1970 r. średni okres oczekiwania na mieszkanie spółdzielcze przekroczył 11 lat (w województwie warszawskim - 18 lat). D. Jarosz, op. cit., s. 238. Rekordowy czas oczekiwania wyniósł podobno 26 lat. A.K. Wróblewski, Dzienniki zabrane przez bezpiekę, Warszawa 2008, s. 278.

${ }^{52}$ Określenie „nowa” jest uzasadnione, jako że w omawianym okresie spółdzielczość ubrano w kostium biurokratycznego molocha kierowanego przez Związek Spółdzielni Mieszkaniowych i Budowlanych. Przedwojenne spółdzielnie, na które przeważnie składały się zespoły kilku niewielkich budynków, a ich władze powoływano spośród grona znających się dobrze spółdzielców, zostały w latach 1951-1954 poważnie ubezwłasnowolnione. K. Madej, Spótdzielczość mieszkaniowa. Wtadze PRL wobec niezależnej inicjatywy społecznej (1961-1965), Warszawa 2003, s. 39 i n. Ustawa z 17 II 1961 r. wprowadziła m.in. zróżnicowanie w zakresie treści spółdzielczego prawa do lokalu. W spółdzielniach potocznie nazywanych lokatorskimi prawo to było niezbywalne i nie podlegało dziedziczeniu. Natomiast w spółdzielniach typu własnościowego obejmowało ono możliwość używania lokalu oraz rozporządzania nim. D. Jarosz, op. cit., s. 51.

${ }^{53}$ Ibidem, s. 88. Wedle czynionych na początku lat sześćdziesiątych założeń w latach 19651970 udział budownictwa spółdzielczego miał wzrosnać do 58\%, zaś udział budownictwa państwowego spaść do $27 \%$. T. Żarski, op. cit., s. 56-57.

54 Ibidem, s. 88.

${ }^{55}$ Ibidem, s. 52. Liczba mieszkań na 1000 mieszkańców wzrosła z 251 w 1960 r. do 264 w 1970 r. D. Jarosz, op. cit., s. 89.

${ }^{56}$ Ibidem, s. 87.

${ }^{57}$ Ibidem, s. 54. 
Ważnym w tej mierze posunięciem stało się zmniejszenie powierzchni mieszkań. O ile w 1959 r. przyjęto, że np. mieszkanie M-1 będzie obejmowało od 17 do $20 \mathrm{~m}$ kw., a mieszkanie M-5 od 51 do $57 \mathrm{~m} \mathrm{kw}$., to w budowanych w latach sześćdziesiątych lokalach uwzględniano tylko dolną granicę wielkości ${ }^{58}$. Zamiast podłóg drewnianych zaczęto stosować tworzywa sztuczne, rezygnowano z obudowywania zlewozmywaków szafkami itp. Symbolem nowych rozwiązań były niskie pomieszczenia z sufitami dostępnymi na wysokości dłoni, z małymi oknami i kuchniami pozbawionymi naturalnego oświetlenia.

Wcześniejsze założenia przewidywały, że wszystkie nowe domy zostana podłączone do wodociąó́w, kanalizacji i elektryczności, a w zależności od warunków lokalnych - także do sieci gazowej. Natomiast w latach sześćdziesiątych inwestycje (zwłaszcza dla budownictwa jednorodzinnego) prowadzono na terenach nieuzbrojonych, przewidując, że np. budowanie studni spadnie na barki zainteresowanych ${ }^{59}$.

Warto wspomnieć w tym miejscu o drobnym wydarzeniu, które świadczyło jednak, że poszukiwania dróg wyjścia z mieszkaniowego kryzysu stawały się stopniowo coraz większym skrzyżowaniem determinacji i bezradności. Otóż w końcu dekady zaczęto w Polsce nagłaśniać wyraźnie ekstrawaganckie propozycje sowieckiego architekta Georgija A. Gradowa z jego książki Miasto $i \dot{z} y c i e^{60}$. Snuł on w niej wizje ,kolektywnego zasiedlenia” likwidującego rodzinne gospodarstwa domowe. Przyszłe aglomeracje składałyby się z zespołów wielkich bloków (np. 30-piętrowych), o niewielkich co prawda lokalach, ściśle za to wplecionych w sieć usług. Zamiast kuchni w każdym mieszkaniu powstać miały zbiorowe jadłodajnie, osiedlowe pralnie, wypożyczalnie odkurzaczy itp. Ta skrajnie antyindywidualistyczna wizja nie zyskała co prawda społecznego uznania, lecz jej dalekie odgłosy dostrzec będzie można w dekadzie gierkowskiej, np. w postaci pomysłu zastapienia prywatnych ciastkarni ogólnokrajową fabryką słodkich wypieków.

W 1958 r. przeciętna liczba izb przypadających w Polsce na jedno mieszkanie wynosiła 2,82, w 1964 r. wzrosła ona do 3, natomiast przeciętna powierzchnia mieszkania zmniejszyła się z $56,7 \mathrm{~m} \mathrm{kw}$. w $1958 \mathrm{r}$. do $50,6 \mathrm{~m} \mathrm{kw}$. $\mathrm{w} 1964 \mathrm{r} .{ }^{61}$ Odsetek ludności żyjącej w mieszkaniach przeludnionych (więcej niż dwie osoby w izbie) wzrósł w latach $1950-1960$ o prawie $34 \%{ }^{62}$. „Jest nas troje dorosłych i w tym pokoju jednym bardzo ciasno, więc stoi łóżko w kuchni - skarżyła się robotnica ze Stołecznych Zakładów Przemysłu Dziewiarskiego - Ale jak się umyć? bo ja mam trzech synów, to się bardzo męczę

\footnotetext{
${ }^{58}$ Ibidem, s. $56-57$.

${ }^{59}$ Ibidem, s. 57.

${ }^{60}$ Instytut Gospodarki Mieszkaniowej opublikował powielaczowe streszczenie tej publikacji, która ukazała się w Moskwie w 1968 r. Zob. Koncepcja mieszkania w przyszłości wg pracy G.A. Gradowa Miasto i życie, oprac. J. Bogusz, Warszawa 1969.

${ }^{61}$ T. Żarski, op. cit., s. 59.

${ }^{62}$ Ibidem, s. 172. Wyjątkiem była jedynie Warszawa, gdzie odsetek ten zmalał o ok. 11\%.
} 
z umyciem. W pokoju śpią i w kuchni też" ". Inna mężatka nie szczędziła słów uznania dla męża, który po powiększeniu się rodziny jakimś „cudem z $10 \mathrm{~m}$ kwadratowych naszego pokoju, które dzielimy z mama, wygospodarował kącik dla dziecka. Na otrzymanie własnego mieszkania nie było żadnych nadziei" 64 .

Z prowadzonych sporadycznie badań ankietowych wynikało, że zainteresowani gotowi byliby czekać dłużej na mieszkanie w zamian za większy metraż, rozsądniej rozplanowane wnętrza zapewniajace lokatorom komfort intymności, staranniejsze wykończenie itp. ${ }^{65}$ Ale budowniczowie nie mieli powodu zmieniać swego działania, gdyż posiadało ono sankcję najwyższych władz partyjno-państwowych. Malkontentom zamykano usta przypominaniem, że na każde zwalniające się miejsce w spółdzielczej kolejce czeka tłum chętnych. Liczba kandydatów i członków spółdzielni wyglądających własnego mieszkania stale rosła, przekraczając w 1969 r. 850 tys. $^{66}$

Obywatele musieli więc sobie radzić sami. Wiele lat później Stanisław Bareja sportretował w serialu Alternatywy 4 spektakl rozpoczynajacy się po przekazaniu kluczy użytkownikom. Ci sami robotnicy, którzy budowali domy „wedle planu”, wkraczali do mieszkań w charakterze prywatnych „fachowców”, aby doprowadzić je do stanu zgodnego z oczekiwaniami lokatorów. W latach sześćdziesiątych widowisko takie było dopiero w powijakach, zarówno ze względu na brak chętnych do pracy wykonawców, jak i drastyczny niedobór materiałów. Daleki od doskonałości wygląd wnętrz stanowił nie tylko skutek pośpiechu, źle rozumianej oszczędności, bałaganu i niechlujstwa socjalistycznej gospodarki, lecz także tego, że przedsiębiorstwom po prostu nie opłacało się kompletne wyposażanie i urządzanie techniczne lokali, albowiem wytwarzanie rozmaitych detali dawało niski „przerób” i było mało opłacalne w systemie, w którym dochody fabryk stanowiły pochodną ciężaru produktów. Toteż zakłady państwowe broniły się, jak mogły, przed produkcją małych przedmiotów i urządzeń, takich jak klamki, krany albo uszczelki; zwłaszcza te ostatnie obrosły w PRL swoistą legendą wskutek permanentnej niedostępności i nietrwałości ${ }^{67}$.

${ }^{63}$ J. Waluk, Ptaca i praca kobiet $w$ Polsce, Warszawa 1965, s. 125-126.

${ }^{64}$ Młodzi po ślubie..., s. 49. Trzeba przypomnieć, że w tradycyjnej rodzinie chłopskiej osiedlenie się młodego małżeństwa w domu rodziców męża lub żony było czymś naturalnym.

${ }^{65}$ W. Czeczerda, Potrzeby i życzenia mieszkaniowe młodych matżeństw członków spółdzielni, Warszawa 1967, passim; Z. Barszczewska, T. Guzek, Z. Pindor, op. cit., s. 35.

${ }^{66}$ D. Jarosz, op. cit., s. 235. W 1957 r. oddano do użytku 122 tys. mieszkań, przy 256,7 tys. zawartych małżeństwach. W 1965 r., przy 200 tys. zawartych małżeństwach, przekazano do użytkowania 168,9 tys. mieszkań. W miastach te proporcje wynosiły: w 1957 r. $-126,8$ tys. małżeństw i 69 tys. mieszkań, w 1965 r. - 102 tys. małżeństw i 131 tys. mieszkań. Na wsi: w 1957 r. - 120,9 tys. małżeństw i 54 tys. mieszkań, w 1965 r. - 98 tys. małżeństw i 37 tys. mieszkań. T. Żarski, op. cit., s. 131.

${ }^{67}$ Uszczelka stała się tytułowym bohaterem pierwszego odcinka serialu telewizyjnego A. Zbycha i A. Konica, pt. Najważniejszy dzień życia (1974). Popełnianie elementarnych błędów budowlanych, używanie materiałów złej jakości i nietrwałych, oddawanie do użytku budynków niewykończonych itp. było wykazywane przez kontrole NIK. D. Jarosz, op. cit., s. 93. 
Poprawa standardów życia dokonywała się nierównomiernie. W skali całego kraju w 1960 r. 98\% ludności zajmowało lokale z energią elektryczną, 55,4\% mieszkań było podłączone do sieci wodociagowej, 35,7\% - do sieci gazowej, $35,6 \%$ ludności miało w mieszkaniach ubikacje, natomiast łazienki - 26\%. Jednakże w liczbach bezwzględnych społeczność żyjąca np. w lokalach bez ubikacji wzrosła z 6,5 mln w 1950 r. do 8,2 mln w 1960 r. $^{68}$

Ustalenia socjologów i dziennikarzy pozwalają zniuansować i uszczegółowić ten ogólny obraz. Dokładna rekonstrukcja warunków bytowych pracowników kilku dużych przedsiębiorstw przemysłowych w Warszawie ${ }^{69}$ pokazywała, że tylko ok. $23 \%$ mieszkało w nowych budynkach. Ponad 57\% pracowników fizycznych dysponowało lokalami z energia elektryczna, ale bez gazu i kanalizacji. Jak wspominała pierwsze miesiące małżeństwa młoda warszawianka, w „pokoju bez wody, gazu, pieca i ubikacji, pośrodku stała dymiąca koza, gotowało się przeważnie na maszynce elektrycznej, a wodę przynosiło się z kamienicznej ubikacji, gdzie ciemne typy piły wódkę, prostytutki uprawiały swój zawód, a tłuste, piszczące szczury uciekały przed delikwentem"70. Około 10\% pracowników uzyskało dostęp do elektryczności i kanalizacji (bez łazienek), za to bez gazu, natomiast ok. 7\% - gazu i elektryczności, lecz bez kanalizacji. Najmniej liczna grupa, dojeżdżających do pracy spoza miasta, nie miała w swych domach nawet prądu ${ }^{71}$.

Sytuacja pracowników umysłowych przedstawiała się nieco lepiej, ok. 23\% korzystało jedynie z elektryczności, natomiast 57\% miało elektryczność, gaz i kanalizację, inna rzecz, że czasem zajmowali mieszkania, gdzie kuchnię, łazienki i ubikację użytkowało kilka rodzin ${ }^{72}$.

Postęp w zakresie dostępu do zdobyczy techniki dokonywał się głównie $\mathrm{w}$ nowych blokach dużych miast. W monitorowanej grupie młodych małżeństw w Warszawie na 10 gospodarstw domowych przypadały w 1963 r.: 1 pralka, 0,3 lodówki, 1 odkurzacz, 5 odbiorników radiowych oraz 1 telewizor. W 1969 r. wskaźniki te wzrosły do 7 pralek, 5,5 lodówek, 6,3 odkurzaczy, 8,5 odbiorników radiowych oraz 6,6 telewizorów $^{73}$.

68 T. Żarski, op. cit., s. 131, 160, 174; D. Jarosz, op. cit., s. 89.

${ }^{69} \mathrm{~W} 1960$ r. przeprowadzono badania kilku przedsiębiorstw - np. Warszawskiej Fabryki Motocykli, Warszawskich Zakładów Przemysłu Odzieżowego, w których wykorzystano m.in. listy płac, indywidualne karty pracownicze, sprawozdania dyrekcji, relacje pracowników. Badane zakłady zatrudniały 5741 pracowników, podczas gdy w całym mieście było 146 przedsiębiorstw (93 tys. pracowników). J. Waluk, Płaca i praca..., s. $183-185$.

${ }^{70}$ Młodzi po ślubie..., s. 287-288.

71 J. Waluk, Ptaca i praca..., s. 107.

72 Ibidem. Mimo że było to sprzeczne z przepisami, spółdzielnie godziły się czasem na to, by jedno mieszkanie zajmowały dwie rodziny. „My mamy dwa pokoje, oni także dwa; kuchnia, ubikacja, korytarz są wspólne" - relacjonowała szczęśliwa z powodu otrzymania przydziału pani inżynier. Młodzi po ślubie..., s. 127.

${ }^{73}$ Z. Barszczewska, T. Guzek, Z. Pindor, op. cit., s. 25-26. 
W zespole badanych w 1960 r. fabryk warszawskich 40\% pracowników umysłowych i $25 \%$ fizycznych dysponowało pralka, $11 \%$ umysłowych i $3 \%$ fizycznych - lodówka, odkurzaczem zaś - 32\% umysłowych i 9\% fizycznych ${ }^{74}$.

Natomiast w skali całego kraju na 100 gospodarstw domowych przypadało w 1960 r. 19 pralek, 1,8 lodówek, 13 maszyn do szycia, 43 radioodbiorniki i 6 telewizorów $^{75}$.

Całkowitym rarytasem, praktycznie niedostępnym dla przeciętnego śmiertelnika, pozostawały telefony. W stolicy w $1957 \mathrm{r}$. odnotowano ok. 40 tys. abonentów, ale większość przypadała na aparaty w różnych biurach i urzędach $^{76}$. Gdy technicy przystapili do instalowania linii w mieszkaniu Kazimierza Dziewanowskiego, zbiegła się cała okolica, a skrupulatny dziennikarz wyliczył, że na obszarze między ulicami 11 Listopada a Szwedzką znajdowały się cztery aparaty telefoniczne, w tym na terenie koszar wojskowych i fabryki, a więc $\mathrm{w}$ miejscach zamkniętych dla przechodniów ${ }^{77}$.

Problemy związane z otrzymaniem, wielkościa, urządzeniem i wyposażeniem mieszkania miały niewątpliwie wpływ na funkcjonowanie polskich rodzin, w tym także na liczebność potomstwa. Różne badania pokazywały, że przeciętne liczby urodzeń były wyższe w wypadku rodzin posiadających mieszkania samodzielne ${ }^{78}$.

Pod względem profilu dzietności Polska upodabniała się stopniowo do krajów rozwiniętych. Na statystyczną Polkę w końcu lat sześćdziesiątych

${ }^{74}$ J. Waluk, Ptaca i praca..., s. 108. Pralka SHL z wyżymaczką kosztowała w 1960 r. 1950 zł, maszyna do szycia z napędem nożnym - 2750 zł, odbiornik radiowy „Preludium” (3-zakresowy) - 1850 zł. Fluktuacje cen zarówno na artykuły spożywcze, jak i przemysłowe były w latach sześćdziesiątych nieznaczne. Kwestia metod ustalania cen to osobne zagadnienie, pominięte w tym artykule.

${ }^{75}$ Kobieta $w$ Polsce..., s. 170. Dostawy do sklepów wzrosły w latach 1955-1960 w dziale lodówek z 2,1 tys. do 53,3 tys., pralek - z 29,7 tys. do 549,1 tys., odkurzaczy - z 6,7 tys. do 130,9 tys., maszyn do szycia - z 50,2 tys. do 148 tys., odbiorników radiowych - z 483,9 tys. do 600,4 tys., telewizorów - z 1,7 tys. do 202,2 tys., wózków dziecięcych - z 207,5 do 209,2 tys. Ibidem, s. 171.

76 Telefonów publicznych, przede wszystkim w budkach ulicznych, było ok. 300, „ale zaledwie połowa z nich jest czynna”. B. Seidler, op. cit. W $1960 \mathrm{r}$. liczba abonentów wzrosła do 75 tys. (66 na 1000 ludności), a w 1965 r. - do 128 tys. (103 na 1000 ludności). Warszawa na tle dużych miast świata, Warszawa 1969, s. 15.

${ }^{77}$ K. Dziewanowski, Świadek w kraju Kafki. Reportaże, Warszawa 1957, s. 23 i n. Niezwykła rzadkością było również posiadanie samochodu (1 na 100 gospodarstw domowych w 1960 , 2,4 w 1965 r.); w 1960 r. na 100 gospodarstw domowych przypadało 10 motocykli i skuterów, w 1965 r. - 17. Motocykl WFM kosztował w 1960 r. 7 tys. zł, rower turystyczny - 992 zł.

${ }^{78}$ Wedle ustaleń Komitetu Nauk Demograficznych PAN przeciętna liczba urodzeń przypadających na jedną kobietę $\mathrm{w}$ mieszkaniach samodzielnych wynosiła 2,5 , w mieszkaniach wspólnych - 1,9. W przypadku mieszkań samodzielnych jednoizbowych wskaźnik ten wynosił 1,9, mieszkań czteroizbowych (i więcej) - 2,7. Wyniki badań nad płodnościa kobiet w Polsce. Wyniki ankiety przeprowadzonej w latach 1963-1964, pod kierunkiem M.J. Ziomka, oprac. E. Vielrose, Warszawa 1967, s. 46. 
przypadało 2,65 dzieci $^{79}$, przy czym wskaźnik ten był najwyższy u mieszkanek wsi, kobiet pracujących fizycznie, jak też posiadających wykształcenie niższe niż średnie.

Bezdzietność występowała kilkanaście razy częściej u kobiet z wykształceniem wyższym niż u kobiet $\mathrm{z}$ wykształceniem podstawowym ${ }^{80}$. Wielodzietność (ponad dwoje dzieci) była częstsza u kobiet biernych zawodowo (47\%) niż u kobiet zawodowo aktywnych (34\%), w tej drugiej grupie zaś częstsza u pracownic fizycznych (36\%) niż umysłowych $(15 \%)^{81}$. Prawie $80 \%$ ankietowanych kobiet do 50. roku życia przyznawało się do stosowania jakiejśs metody kontroli narodzin ${ }^{82}$.

$\mathrm{Na}$ liczebność rodziny wpływały nie tylko czynniki ekonomiczne, lecz także poziom wykształcenia, aktywność zawodowa kobiet oraz fluktuacje ambicji życiowych małżonków. Niezależnie od powodów ograniczenie dzietności u kobiet pracujących było na tyle widoczne, że socjologowie postulowali dynamizację polityki społecznej, m.in. tworzenie systemu przywilejów dla rodzin wielodzietnych ${ }^{83}$.

Wedle dominujących wówczas zwyczajów ciężar odpowiedzialności za wychowanie dzieci, zwłaszcza w fazie niemowlęcej, spoczywał na barkach płci pięknej. W latach pięćdziesiątych propaganda posługiwała się hasłem: „żadna kobieta nie rodzi w domu!" Nawoływanie to okazało się skuteczne, bo w końcu dekady $74 \%$ noworodków przychodziło na świat w szpitalach, a $19 \%$ - w izbach porodowych. Opieka szpitalna miała zapewnić przyszłej matce komfort i bezpieczeństwo, lecz praktyka okazywała się bardziej złożona. Służba zdrowia nie zawsze była przygotowana do nowych wyzwań, zarówno w aspekcie materialno-organizacyjnym, jak i etycznym. Problemy te uwidoczniła nagłośniona w okresie „odwilży” dramatyczna historia mieszkanki wsi Dudki ${ }^{84}$. Przywieziona furmanką przez męża do odległego o $25 \mathrm{~km}$ szpitala w Garwolinie została zbadana przez położną (lekarz się nie pojawił),

${ }^{79} \mathrm{~W}$ miastach - 2,18, na wsi - 3,17. B. Łobodzińska, Rodzina w Polsce..., s. 47. Wskaźnik urodzeń żywych na 1000 kobiet w wieku do 49 lat wynosił na początku lat sześćdziesiątych w Polsce 58, w Austrii - 71, Bułgarii - 54, Czechosłowacji - 61, Danii - 63, Francji - 69, Grecji - 58, Hiszpanii - 72, Holandii - 74, Jugosławii - 76, NRD - 68, RFN - 68, Portugalii - 80, Rumunii - 51, Szwecji - 55, Wielkiej Brytanii (bez Szkocji) - 70, ZSRR - 74. Kobieta w Polsce..., s. 196.

${ }^{80} \mathrm{~W}$ tej pierwszej kategorii - 16\%, w drugiej - 1\%. Prawie co czwarta rodzina wiejska miała więcej niż troje dzieci, podczas gdy odsetek rodzin miejskich posiadających od 1 do 3 dzieci wynosił 91,6\% (dane z 1960 r.). B. Łobodzińska, Rodzina w Polsce..., s. 119.

81 Wyniki badań..., s. 68.

${ }^{82}$ Ibidem, s. 96. Z danych zgromadzonych w latach 1966-1968 wynika, że najczęstszą metodą antykoncepcji były prezerwatywy, a podstawową metodą kontroli urodzin stosowanie tzw. kalendarzyka małżeńskiego. Środków antykoncepcyjnych dla kobiet używano sporadycznie i nie miały wpływu na regulację urodzin. B. Łobodzińska, Rodzina w Polsce..., s. 116.

${ }^{83}$ Ibidem, s. 121.

${ }^{84}$ Historia ta rozegrała się w październiku 1954 r. K. Dziewanowski, op. cit., s. 126 i n. 
która stwierdziła, że poród może nastapić lada chwila. W placówce brakowało jednak wolnych miejsc, więc kobieta przesiedziała całą dobę na ławce w korytarzu. Nie dano jej koca, poduszki ani niczego do picia. Po 24 godz. wystapiły bóle porodowe, ale i wówczas nikt nie zajął się młodą chłopka, która urodziła w poczekalni izby przyjęć w pozycji półstojącej, wobec czego noworodek uderzył główką w podłogę. Dopiero wtedy lekarze i pielęgniarki przystapili do działania, polegającego głównie na fałszowaniu dokumentacji medycznej z zamiarem wykazania, że dziecko było martwe już przed porodem. Sprawa zakończyła się przed sądem, który skazał czterech pracowników szpitala na kary od ośmiu miesięcy do półtora roku więzienia w zawieszeniu. Co znamienne, biegli sądowi, czyli też medycy, opiniowali jednoznacznie na niekorzyść oskarżonych, którzy bronili się argumentem, że nie złamali żadnego przepisu. Bo przecież lekarz dyżurny nie ma obowiązku badania położnicy, nie musi też kontrolować działań położnej, taka samo jak ordynator nie jest zobligowany sprawdzać, co się dzieje w izbie przyjęć...

$\mathrm{Na}$ oddziały położnicze w szpitalach nie wpuszczano odwiedzających, co miało uzasadnienie $\mathrm{w}$ realiach $\mathrm{w}$ zakresie higieny, lecz zarazem $\mathrm{w}$ sposób symboliczny odgradzało mężczyzn od sfery narodzin. Jak to ujmowali z życzliwa złośliwością publicyści, rola ojca w ostatniej fazie ciąży i w chwili porodu sprowadzała się do „zdobywania” pieluch, przekupywania portierów, aby dostarczyli nielegalnie kwiaty młodej matce, a wreszcie upicia się ze szczęścia razem z kolegami z pracy. Dlatego też adresatem większości regulacji prawnych związanych z rodzeniem i wychowywaniem dzieci były kobiety.

W rodzinie tradycyjnej żona bądź nie pracowała zawodowo, bądź przerywała prace po urodzeniu dziecka. W latach sześćdziesiątych tego rodzaju nastawienie utrzymywało się w wielu środowiskach robotniczych, co potwierdzały m.in. badania prowadzone na Ślasku, Łodzi i w Warszawie ${ }^{85}$. Wyznawali je nie tylko mężczyźni, ale i kobiety. Do głównych argumentów należało przekonanie, że nieobecność matki w domu utrudnia wychowywanie dzieci i dezorganizuje życie rodzinne ${ }^{86}$. Co najważniejsze - alarmował jeden z małżonków - „kobietę trzeba trzymać w garści”, bo inaczej „to zdradzi”, a wychodzenie z domu dostarcza ku temu okazji ${ }^{87}$.

\footnotetext{
${ }^{85}$ A. Kłoskowska, op. cit.; W. Mrozek, op. cit.; F. Jakubczak, Badania postaw warszawskich metalowców, „Przegląd Socjologiczny” 1960, nr 1. W 1956 r. robotnicy niektórych fabryk, obawiający się redukcji zatrudnienia, domagali się zwolnienia z pracy wszystkich mężatek. A. Leszczyński, Sprawy do załatwienia. Listy do „Po Prostu” 1955-1957, Warszawa 2000, s. $120-121$.

${ }^{86}$ Przeciwnicy aktywności zawodowej kobiet uważali, że skoro w pracy wymaga się od nich zdecydowania, twardości, samodzielności itp., to wskutek tego stają się mniej uczuciowe, mniej ciepłe i uległe, nie mają też czasu na pielęgnowanie urody. M. Sokołowska, Kobieta pracujaca. Socjomedyczna charakterystyka pracy kobiet, Warszawa 1963, s. 149.

${ }^{87}$ Jaka jesteś, rodzino?..., s. 46.
} 
Aktywizujące się zawodowo żony oczekiwały bowiem przejęcia przez mężów części domowych obowiązków, na co ci, walczący o utrzymanie prymatu $\mathrm{w}$ rodzinie, nie chcieli się zgodzić. W męskim odczuciu praca stanowiła dla kobiet wygodną ucieczkę od monotonii zajęć domowych.

Sprawa wychowania dzieci jest ważniejsza niż rozrywki kobiet, bo tak kobiety traktuja pracę - tłumaczył swe stanowisko 26-letni inżynier - Żony nasze są ciagle zmęczone, zalatane, chore i trzeba przyznać, że chętnie chodzą do pracy, bo przez te 8 godzin odrywają się od smętnej rzeczywistości, jaką jest dom. [...] Ja się na to nie zgadzam ${ }^{88}$.

\section{Po drugiej stronie rozlegały się głosy „emancypantek”.}

Nie lubię prasować męskich spodni ani koszul - podkreślała 19-letnia panna - Nie lubię gotować ani prać, ani niańczyć dzieci. To chyba dlatego, że w domu mam dwóch mężczyzn (ojca i brata), których matka stale obsługuje i którzy uważają kobiety za coś niższego od siebie ${ }^{89}$.

Omawiając te kwestie, trzeba zwrócić uwagę, że prace domowe wymagały w latach sześćdziesiątych większego wysiłku fizycznego niż obecnie. W ich zakres wchodziły takie czynności, jak regularne zagniatanie ciasta do posiłków, czyszczenie kuchni i pieców węglowych, łącznie z przynoszeniem opału i wynoszeniem popiołu, trzepanie dywanów, ręczne pranie oraz wyżymanie upranej bielizny itp. Obliczenia Instytutu Fizjologii Pracy w Dortmundzie pokazywały, że zużycie kalorii przy tych działaniach było porównywalne ze średnim zużyciem kalorii przez mężczyzn pracujących fizycznie ${ }^{90}$.

W 1960 r. udział kobiet w zatrudnieniu poza rolnictwem wynosił $35 \%$, a w 1965 r. - 37\% ${ }^{91}$. Odsetek ten był wyższy niż w RFN (34\%) czy Szwecji

${ }^{88}$ B. Łobodzińska, Młodość, miłość..., s. 236. Korespondowała z tym wypowiedź robotnicy z Warszawskich Zakładów Przemysłu Odzieżowego, która - jak mówiła - „właściwie do fabryki przychodzi odpocząć. W domu to pracuję!...” J. Waluk, Ptaca i praca..., s. 126. Badania ankietowe, przeprowadzone w $1961 \mathrm{r}$. w fabrykach warszawskich, pokazały, że 80\% mężczyzn pracujących fizycznie było przeciwnych pracy zarobkowej kobiet, z pozostałych, dopuszczających taką możliwość, jedynie 6\% uważało, że kobiety moga pracować z innych powodów niż potrzeby materialne. Ankietowanych nie dziwiła lekarka czy farmaceutka, raziła ich natomiast kobieta w roli konduktorki, motorniczego czy inżyniera. Spośród mężczyzn pracujących umysłowo przeciwko pracy kobiet wypowiadało się 53\%, z tym że $42 \%$ miało zastrzeżenia jedynie wobec pracy zarobkowej mężatek posiadających dzieci. Ibidem, s. 66-71.

89 B. Łobodzińska, Młodość, miłość..., s. 238.

${ }_{90}$ H. Strzemińska, Praca zawodowa kobiet a ich budżet czasu, Warszawa 1970, s. 92-93. Badania nad budżetem czasu prowadziły różne instytucje, analizując sytuację wybranych grup zawodowo-społecznych. Podstawą ustaleń autorki były m.in. badania próby reprezentatywnej ogółu zatrudnionych w Toruniu.

91 A. Kurzynowski, Ciagłość pracy a macierzyństwo, Warszawa 1967, s. 18. W 1960 r. wśród kobiet w wieku 20-29 lat odsetek czynnych zawodowo wynosił 29\%, w grupie 30-39 lat 
(33\%), niższy niż w Austrii (40\%) lub Czechosłowacji (43\%) ${ }^{92}$. Kobiety częściej niż mężczyźni wykonywały pracę umysłową $a^{93}$ a reprezentantkami postępującej feminizacji niektórych zawodów stały się nauczycielki, farmaceutki, pielęgniarki, sprzedawczynie, sekretarki i dentystki ${ }^{94}$.

Badania ankietowe pokazywały, że tak w miastach, jak i na wsi decyzja pójścia do pracy miała trzy główne powody: chęć poprawy sytuacji materialnej, pragnienie wykorzystania posiadanego wykształcenia ${ }^{95}$, potrzebę wypełnienia czasu wolnego. Ten ostatni motyw był w statystykach marginalny, dominował czynnik pierwszy, zwłaszcza wśród wdów i rozwódek, rzadziej u panien i mężatek.

Z powyższego obrazu wynikało, że znaczny odsetek kobiet porzuciłby pracę w wypadku poprawy domowych finansów, np. w efekcie wyższych zarobków

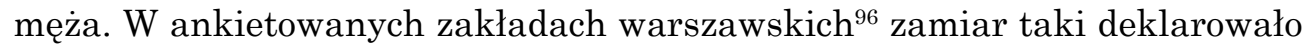
$78 \%$ pracownic fizycznych i $62 \%$ pracownic umysłowych. Pragnienie kontynuowania aktywności zawodowej podkreślało tylko 4\% pracownic fizycznych i $12 \%$ pracownic umysłowych, reszta zaś nie miała jasności poglądów w tym zakresie ${ }^{97}$.

Wszystkie źródła zgodnie poświadczały, że kobiety w latach sześćdziesiątych zarabiały mniej niż mężczyźni, pracowały bowiem w zawodach i na stanowiskach gorzej wynagradzanych ${ }^{98}$. Nawet jeśli np. w przemyśle średnia

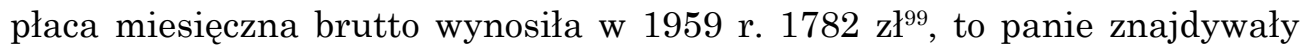

- 51\%, w grupie 40-49 lat - 48\%, zaś w grupie 50-59 lat - 33\%. J. Piotrowski, Praca zawodowa kobiet poza domem, w: Kobieta wspótczesna. Z badań socjologów, lekarzy, ekonomistów, pedagogów i psychologów, red. M. Sokołowska, Warszawa 1966, s. 19. W 1960 r. kobiety stanowiły 55\% ogółu czynnych zawodowo w rolnictwie. Kobieta w Polsce..., s. 49. W odniesieniu do wcześniejszego okresu kwestie te omawia N. Jarska, Kobiety z marmuru. Robotnice $w$ Polsce $w$ latach 1945-1960, Warszawa 2015. Zob. też: M. Fidelis, Kobiety, komunizm i industrializacja $w$ powojennej Polsce, tłum. M. Jaszczurowska, Warszawa 2015.

${ }^{92}$ A. Preiss-Zajdowa, Preferencje zawodowe kobiet $w$ Polsce, w: Kobieta wspótczesna..., s. 157.

${ }^{93}$ A. Kurzynowski, op. cit., s. 19 . W 1960 r. 39\% pracujaccych poza rolnictwem kobiet zatrudnionych było w przemyśle, $17 \%$ - w handlu, $12 \%$ - w oświacie, nauce i kulturze, $10 \%$ - w służbie zdrowia i opiece społecznej. Kobieta $w$ Polsce..., s. 58. Wyższy niż 50\% odsetek kobiet wśród ogółu zatrudnionych dotyczył przemysłu odzieżowego, skórzanego, futrzarskiego i obuwniczego, najniższy (20-10\%) m.in. metalowego, hutniczego i paliwowego (dane z 1960 r.). J. Waluk, Ptaca i praca..., s. 46-47.

${ }^{94}$ Rodzina $w$ Polsce..., s. 95.

${ }^{95}$ Spośród kobiet z wykształceniem wyższym pracowało $86 \%$, a spośród kobiet z wykształceniem podstawowym - 46\%. A. Kurzynowski, op. cit., s. 105.

${ }^{96}$ Zob. przypis 69.

97 J. Waluk, Płaca i praca..., s. 123-124, 133-134.

${ }_{98}$ Eadem, O płacy kobiet w Polsce, w: Kobieta wspótczesna..., s. 175. Wśród pracowników fizycznych w przemyśle maksymalna granica udziału kobiet w zatrudnieniu wedle wysokości zarobków w 1960 r. to 3,5 tys. zł, u mężczyzn - ponad 6 tys. zł. Wśród pracowników umysłowych z wyższym wykształceniem ponad połowa kobiet zarabiała do 2 tys. zł, ponad połowa mężczyzn powyżej 2 tys. zł. Odsetek mężczyzn w tej kategorii zarabiających powyżej 3 tys. zł wynosił 35\%, a kobiet tylko - 3,3\%. Eadem, Płaca i praca..., s. 26-28.

${ }^{99} \mathrm{~W}$ całej gospodarce uspołecznionej średnia ta wynosiła $1625 \mathrm{zł}$. 
zatrudnienie przede wszystkim we względnie upośledzonych pod tym względem branżach, jak chociażby przemysł włókienniczy (średnia 1400 zł) ${ }^{100}$. Niektóre zajęcie traktowano w społecznym stereotypie jako „kobiece”, czyli „lżejsze”, stąd salowa w szpitalu przynosiła do domu mniej pieniędzy niż powiedzmy portier w fabryce.

Na wysokość dochodów wpływał częściowo poziom wykształcenia, który pozostawiał wówczas wiele do życzenia. W skali całego kraju prawie ok. $70 \%$ zatrudnionych $\mathrm{w}$ gospodarce uspołecznionej posiadało zaledwie wykształcenie podstawowe pełne lub niepełne (dane z 1959 r.). Odsetek kobiet o takich kwalifikacjach wynosił $60 \%$, przy czym ponad połowę liczebności tej grupy stanowiły osoby urodzone w 1923 r. i wcześniej ${ }^{101}$. Najgorzej wykształceni pracowali przede wszystkim w przemyśle, a do najmniej zarabiających należeli pracownicy przemysłu tekstylnego, gumowego i spożywczego, gdzie znacząca była obecność kobiet ${ }^{102}$.

Niższy poziom kwalifikacji zawodowych stanowił najsłabszy punkt sytuacji kobiet. Przepytywane pracownice badanych fabryk warszawskich nie były skłonne do podnoszenia swych umiejętności, tłumacząc się brakiem czasu i nieopłacalnością takiego wysiłku, który nie przynosił ani awansu, ani podwyżki płac w sposób automatyczny. Najmłodsze z nich traktowały ponadto podjęcie pracy jako etap przejściowy na drodze do zamążpójścia ${ }^{103}$. Ten brak zapału do kształcenia odpowiadał zarządzającym przedsiębiorstwami, albowiem cechą gospodarki rozwijanej w wariancie ekstensywnym było duże zapotrzebowanie na pracę nisko kwalifikowaną i słabo wynagradzaną.

100 J. Waluk, Ptaca i praca..., s. 80.

101 Spośród kobiet pracujących w przemyśle 51\% miało wykształcenie podstawowe, a 34\% podstawowe niepełne; wśród pracujacych w handlu wykształcenie podstawowe posiadało $52 \%$, a wykształcenie podstawowe niepełne - 14\%; wśród zatrudnionych w oświacie, kulturze i nauce $42 \%$ miało wykształcenie średnie zawodowe, 16\% - wykształcenie podstawowe, $14 \%$ - wykształcenie podstawowe niepełne, a $12 \%$ - wykształcenie wyższe; wśród pracujących w służbie zdrowia i opiece społecznej $34 \%$ posiadało wykształcenie podstawowe, $22 \%$ - wykształcenie podstawowe niepełne, a $19 \%$ - średnie zawodowe. Kobieta $w$ Polsce..., s. 65.

102 Wedle wyników tzw. spisu kadrowego GUS z 1968 r. wśród ogółu zatrudnionych 16,4\% miało wykształcenie podstawowe niepełne (wśród mężczyzn - 17,8\%, wśród kobiet 14,3\%), 44\% - wykształcenie podstawowe ( $\mathrm{M}$ - 45,3\%, K - 41,4\%), 15,3\% - zasadnicze zawodowe ( $\mathrm{M}-17,7 \%, \mathrm{~K}-11,5 \%), 3,8 \%$ - niepełne średnie ogólnokształcące ( $\mathrm{M}-2,5 \%$, $\mathrm{K}-5,8 \%), 4,5 \%$ - średnie ogólnokształcące (M - 2,7\%, K - 7,4\%), 11,3\% - średnie zawodowe $(\mathrm{M}-8,8 \%, \mathrm{~K}-15,3 \%)$, a $4,5 \%$ - wyższe ( $\mathrm{M}-5,1 \%, \mathrm{~K}-4,7 \%)$. H. Strzemińska, op. cit., s. 171. W roku akademickim 1960/1961 odsetek studentek wynosił 38\% (w roku akademickim 1970/71 wzrósł do 43\%). Najwięcej dziewcząt uczęszczało na studia humanistyczne, medyczne i ekonomiczne. Rodzina $w$ Polsce..., s. 97. W tym samym czasie odsetek kobiet na studiach wyższych wynosił w Czechosłowacji $34 \%$, w NRD - 32\%, we Francji - 37\%, w RFN - 20\%. M. Sokołowska, K. Wrochno, Pozycja społeczna kobiet $w$ świetle statystyki, w: Kobieta wspótczesna..., s. 60.

103 J. Waluk, Ptaca i praca..., s. 140-143. 
Wskutek rozmaitych uprzedzeń kobiety rzadko zajmowały stanowiska kierownicze ${ }^{104}$. W $1959 \mathrm{r}$. funkcje dyrektora w przedsiębiorstwach przemysłowych piastowało ok. 5 tys. mężczyzn i 108 kobiet. Od tych ostatnich wymagano wysokich kwalifikacji i długiego stażu pracy, których to warunków nie musieli spełniać mężczyźni, a niektórzy z nich nie posiadali nawet wykształcenia podstawowego ${ }^{105}$.

Należy wreszcie wspomnieć o niskiej aktywności społecznej kobiet, szczególnie wśród załóg robotniczych, ich niezdolności do tworzenia grup nacisku. Ilustracją tego może być przypadek Warszawskich Zakładów Odzieżowych nr $2 \mathrm{w}$ Warszawie: ich załoga liczyła ok. 2 tys. pracownic i ok. 300 pracowników, ale w wyborach do Rady Robotniczej spośród 36 miejsc tylko dwa zajęły kobiety, zreszta pracownice umysłowe. Nie mamy do siebie zaufania, tłumaczyły robotnice, „niech mężczyźni kieruja, oni są mądrzejsi, lepiej się na wszystkim znaja”" ${ }^{106}$.

Przypisywanie mężczyznom monopolu na mądrość kończyło się wszakże $\mathrm{w}$ chwili dysponowania zarobionymi pieniędzmi. $\mathrm{Z}$ badań ankietowych wynikało, że mężowie bardzo rzadko zarządzali samodzielnie rodzinnym budżetem. Przeważnie czyniły to żony, zwłaszcza gdy same też pracowały, natomiast o wydatkach większego kalibru decydowali wspólnie obydwoje małżonkowie ${ }^{107}$. Realia ekonomiczne nie stwarzały zresztą wielkiego pola manewru. Przeciętny przychód na 1 osobę rocznie wśród zatrudnionych poza rolnictwem i leśnictwem wynosił w 1963 r. 12994 zł (44 310 zł na jedno gospodarstwo domowe, liczące średnio 3,41 osób) ${ }^{108}$. Rodziny, w których przychody na 1 osobę rocznie nie przekraczały 7200 zł, stanowiły $9,5 \%$ ogółu, a te z przychodami powyżej 25 tys. $-6,7 \%$. Najliczniejsi byli swego rodzaju „średniacy”, o przychodach między 7201 a 15 tys. zł (59\%).

Większość rozchodów (w przeliczeniu na jedną osobę) przeznaczano na zakup żywności $(43,2 \%)$, pozostałe pozycje $\mathrm{w}$ domowym budżecie to zakup odzieży i obuwia (14,3\%), pokrycie kosztów edukacji (podręczniki, przybory szkolne itp.), rozrywek kulturalnych i turystyki $(6,8 \%)$, opłaty za mieszkanie $(6,5 \%)$, wydatki na higienę i ochronę zdrowia $(5,1 \%)$ oraz opłaty za opał i światło $(3,4 \%)^{109}$. Ceny w sklepach uspołecznionych zmieniały się w latach

${ }^{104}$ Dziennikarze odnosili się niekiedy z widoczną ironią do „nadmiernych” oczekiwań kobiet, które wyrażała jedna z interesantek w urzędzie zatrudnienia, zarzekająca się, że „nie będzie segregować listów za 700 złotych, nie na to szkoły kończyła”. A. Wysznacka, Warszawa - Biuro Pośrednictwo Pracy (Jeden dzień w Polsce), „Nowa Kultura” 1957, nr 9.

105 J. Waluk, Ptaca i praca..., s. 97.

106 A. Barlińska, Babskie i nie-babskie sprawy, „Walka Młodych” 1957, nr 2.

107 J. Piotrowski, Praca zawodowa kobiet a rodzina, Warszawa 1963, s. 290-291.

${ }^{108} \mathrm{~W}$ statystykach na przychody składały się dochody z pracy (ok. 85,5\%), świadczenia społeczne (ok. 9\%) oraz takie pozycje, jak wpływy ze sprzedaży mienia, z opłat za wynajem mieszkania, za stołowanie i inne usługi.

${ }^{109}$ Rodziny pracowników fizycznych przeznaczały nieco więcej niż rodziny pracowników umysłowych na żywność, a nieco mniej na oświatę, kulturę i turystykę. 
1960-1965 minimalnie ${ }^{110}$. Wprawdzie z powyższego wynikało, że większość przychodów była konsumowana na potrzeby bieżące, ale statystyczny Polak posiadał jednak w 1957 r. 255 zł oszczędności (ulokowanych przede wszystkim w PKO), natomiast w 1963 r. - już 1280 zł.

Narodziny dziecka stawały się wyzwaniem dla rodziny. Pracujacca zawodowo matka mogła po porodzie korzystać z 12 tygodni urlopu ${ }^{111}$. Urlopy te były w Polsce krótsze, a dodatki rodzinne niższe niż np. w Bułgarii, Czechosłowacji i na Węgrzech.

Po wykorzystaniu urlopu zainteresowane stawały przed pytaniem, czy wrócić do pracy zawodowej, czy pozostać $\mathrm{w}$ domu. W Polsce matki decydowały się na to pierwsze częśsiej niż $\mathrm{w}$ innych krajach. W modelu anglosaskim kobiety szły do pracy w wieku 17-19 lat, przerywały ja po mniej więcej 4 latach, z powodu wyjścia za mąż, a powracały po przerwie trwającej 8-10 lat ${ }^{112}$.

Natomiast w modelu polskim aktywność zawodowa kobiet przed małżeństwem była wysoka ${ }^{113}$, ślub nie stanowił przeszkody w kontynuowaniu pracy, dopóki nie pojawiło się dziecko, ale przerwy w zatrudnieniu spowodowane macierzyństwem trwały tylko ok. 3 lat. Po 6 miesiaccach od zakończenia urlopu 70\% matek kontynuowało pracę, natomiast w ciagu 3 lat od urodzenia wskaźnik ten wzrastał do $78 \%{ }^{114}$. W 1960 r. mężatki stanowiły $55 \%$ ogółu kobiet pracujacych poza rolnictwem ${ }^{115}$. Przy tym wszystkim aktywność zawodowa dotyczyła przede wszystkim osób względnie młodych, z wiekiem zaczynała ona maleć ${ }^{116}$, co było odwrotną tendencją w porównaniu z takimi krajami, jak Dania, Francja i Szwecja.

Wznawianie pracy miało głównie powody materialne, natomiast rezygnujące z niej nie potrafiły pogodzić działalności zawodowej z obowiązkami domowymi. Liczniej kontynuowały pracę mężatki z wykształceniem wyższym i średnim zawodowym, częściej wracały do pracy matki starsze niż młodsze,

${ }^{110}$ I tak za kilogram chleba trzeba było zapłacić 3,5 zł, mąki - 6,7 zł, cukru - 12 zł, łopatki wieprzowej - $36 \mathrm{zl}$, kiełbasy zwyczajnej $-36 \mathrm{zł}$, margaryny $-28 \mathrm{zł}$, masła $-70 \mathrm{zł}$, za butelkę piwa - 2,4 zł, wódki czystej (0,5 l) - 48 zł, paczkę najtańszych papierosów - 3 zł. Zakup męskiego garnituru oznaczał wydatek rzędu 660-1860 zł, płaszcza - 700 zł, pary butów damskich - powyżej $190 \mathrm{zl}$, a męskich - powyżej $260 \mathrm{zł}$. Tona węgla kosztowała $500 \mathrm{zl}, 1 \mathrm{~m}^{3}$ gazu - 0,50 zł, $1 \mathrm{kWh}$ energii elektrycznej - 0,39 zł, komorne za $1 \mathrm{~m}^{2}-$ 0,77 zł, miesięczny abonament radiowy - $15 \mathrm{zl}$, a telewizyjny - $40 \mathrm{zł}$. Ceny żywności na targowiskach zmieniały się w zależności od sytuacji na rynku.

111 B. Łobodzińska, Rodzina $w$ Polsce..., s. 91.

112 A. Kurzynowski, op. cit., s. 48-49.

${ }^{113}$ W miastach wśród ogółu kobiet niezamężnych w wieku 18-29 lat pracowało 80,6\%. Ten wskaźnik był jednak niższy niż u mężczyzn (95\%). Ibidem, s. 63.

114 Ibidem, s. 66.

${ }^{115}$ Kobieta $w$ Polsce..., s. XVIII.

${ }^{116} \mathrm{~W}$ kategorii wiekowej 20-24 lat pracowało 61\% kobiet, w kategorii 25-34 lat - 50\%, w kategorii 35-44 lat - 47\%, w kategorii 45-54 lat - 40\%, w kategorii 55-64-23\%. M. Sokołowska, K. Wrochno, op. cit., s. 48-49. 
matki mające więcej niż jedno dziecko niż matki z jednym dzieckiem, jak też matki z rodzin mieszkajacych $\mathrm{z}$ teściami i rodzicami ${ }^{117}$.

Podział obowiązków w rodzinie okazywał się trudny do przeprowadzenia. Częściej partycypowali w pracach domowych pracownicy umysłowi niż fizyczni, ale i tak większość czynności, a więc zakupy żywności, gotowanie, sprzątanie i zmywanie, pranie itp., wykonywały w ponad $80 \%$ kobiety ${ }^{118}$. Nie odbiegało to od sytuacji w wielu innych krajach, bo np. we Francji, Czechosłowacji i na Węrzech gotowaniem, sprzątaniem i praniem zajmowały się głównie żony, mężowie byli natomiast bardziej widoczni przy sprzątaniu posesji i uprawianiu ogródka, zakupach oraz naprawach ${ }^{119}$.

Podjęcie pracy zarobkowej przez kobietę wpływało więc, chcąc nie chcąc, na funkcjonowanie rodziny. W Toruniu np. (badania przeprowadzone przez Instytut Pracy i Polską Akademię Nauk) mężatki po zatrudnieniu musiały redukować czas przeznaczony na przygotowywanie posiłków i sprzątanie o ok. $40 \%$, a czas zakupów o $50-60 \%{ }^{120}$.

W Polsce sieć tzw. usług była słabiej rozwinięta w porównaniu z innymi krajami ${ }^{121}$. Polki i Polacy rzadko korzystali ze stołówek, a gęstość placówek gastronomicznych (abstrahując od jakości oferowanego tam menu), jak również sklepów także przedstawiała się gorzej niż u bliższych lub dalszych sąsiadów $^{122}$.

117 Ibidem, s. 67. Stopień kontynuacji pracy wśród pracownic biurowych wynosił ok. 70-80\%, wśród innych pracujących umysłowo - 60-90\% (wśród kierowniczek szkół 100\%), wśród pracujących fizycznie - 40-60\%. Spośród pracujących umysłowo najczęściej kontynuowały pracę nauczycielki, lekarki, farmaceutki. Ibidem, s. 96-97.

118 Sytuacja nie była jednak jednorodna. Z badań nad funkcjonowaniem rodzin w Warszawie wynikało, że ok. $60 \%$ mężczyzn skłonnych było wynosić śmieci, reszta obowiązków spadała na panie domu, przy czym najbardziej „kobiecymi” zajęciami okazywały się pranie, mycie okien i robienie zakupów spożywczych. Inaczej jednak wyglądała sytuacja np. w Nowej Hucie, gdzie kobiety mogły liczyć na duże wsparcie członków rodziny w zakresie zakupów, sprzątania i zmywania. B. Łobodzińska, Rodzina w Polsce..., s. 105. Z kolei w Toruniu ok. $52 \%$ robotnic, $42 \%$ urzędniczek i $52 \%$ pracownic handlu nie miało w pracach domowych żadnej pomocy. H. Strzemińska, op. cit., s. 56-57.

119 Ibidem, s. 58-59.

120 Ibidem, s. 51.

121 Odsetek pracujacych w usługach wynosił $25 \%$ ogółu zatrudnionych ('średnia światowa to $27 \%$ ), podczas gdy w Czechosłowacji kształtował się on na poziomie 32\%, w NRD - 35\%, w Danii - 46\%, Francji - 42\%, Szwecji - 41\%. W bloku sowieckim gorzej od Polski prezentowały się Albania (15\%) i Bułgaria (20\%). Ibidem, s. 190.

${ }^{122} \mathrm{~W}$ Warszawie funkcjonowały w 1960 r. 394 zakłady gastronomiczne (w tym 209 restauracji), czyli 1 na 2837 mieszkańców. W Berlinie odpowiednio 984 (229) - 1 na 1096 mieszkańców, w Budapeszcie 800 (782) - 1 na 2305 mieszkańców, w Pradze - 1828 (1305) - 1 na 550 mieszkańców. Stolica Polski miała w 1960 r. 4237 sklepów i 7 domów towarowych (1 sklep na 264 osoby), Berlin (w 1965 r.) - 6117 sklepów i 16 domów towarowych (1 na 176 osób), Budapeszt - 6980 sklepów i 23 domy towarowe (1 na 264 osoby), a Praga 5536 sklepów i 10 domów towarowych (1 na 182 osoby). Warszawa na tle dużych miast..., s. 18. 
Nie przyjęły się instytucja osiedlowych pralni samoobsługowych ani zwyczaj oddawania bielizny i ubrań do pralni publicznych ${ }^{123}$. Za potrzebami obywateli nie nadążała miejska i pozamiejska komunikacja. Była to kwestia o tyle istotna, że w 1964 r. 19,8\% ogółu zatrudnionych (ok. 1,5 mln osób) dojeżdżało do pracy z sąsiednich powiatów. Na problem składały się nie tylko długość tras dojazdowych, ale i ilość czasu niezbędnego do ich pokonania. Trasy mieściły się w przedziale $30-40 \mathrm{~km}$, przy czym średnia krajowa wynosiła $15,5 \mathrm{~km}$ w jedna stronę. Pracownik zamiejscowy poświęcał na dojazdy przeciętnie 46 minut w jedną stronę; nawet przy małych odległościach (7-10 km) przejazdy trwały w Polsce dłużej niż w Bułgarii czy na Węgrzech, nie mówiąc już o takich krajach, jak Belgia i Francja ${ }^{124}$.

Rozbudowa sieci żłobków i przedszkoli nie nadążała za potrzebami ${ }^{125}$, wobec czego w pejzażu rodzinnym ważną rolę odgrywała instytucja babci, która z mniejszym lub większym zapałem wcielała się w rolę gosposi, niani i przedszkolanki. Młode mężatki czasem narzekały na wścibstwo, apodyktyczność i „,szarogęsienie się” matek lub teściowych, ale pomoc z ich strony traktowały jako coś, co im się bezwzględnie należy. „Uważałam, że teściowa winna była zajać się szczerze domem i dzieckiem - utyskiwała jedna z ankietowanych - Nie była ani chora, ani też w sędziwym wieku. Niestety, poza drobnymi przysługami nie chciała się włączyć bardziej czynnie w nasze życie"126.

W Toruniu wśród zatrudnionych w handlu z takiego wsparcia korzystało ok. $60 \%$ kobiet z dziećmi w wieku przedszkolnym i ok. 50\% z dziećmi uczęszczającymi do szkół. Na Ślassku ok. 33\% rodzin miejskich mieszkało wspólnie z rodzicami męża lub żony, zaś następne $20 \%$ posiadających dzieci korzystało z babć „dochodzących”. W szkolnych świetlicach frekwencja była niewielka, dzieci w wieku powyżej 10 lat traktowano już jako dostatecznie dorosłe, aby mogły funkcjonować samodzielnie po powrocie do domu. Czyniło tak 30\% fizycznych i $15 \%$ pracownic umysłowych w przebadanej społeczności toruńskiej ${ }^{127}$.

Badania UNESCO, prowadzone w Europie w pierwszej połowie lat sześćdziesiątych, pokazywały, że kobiety poświęcały na obowiązki domowe między 4 a 5 godz. dziennie, średnio o 3 godz. więcej niż mężczyźni. Po odliczeniu wszystkich zajęć i snu na czas wolny pozostawało kobietom w Jugosławii i na Węgrzech ok. 2 godz. (mężczyznom - 4 godz.), natomiast kobietom w RFN - 3 godz. 50 minut (mężczyznom - 4 godz. 40 min) ${ }^{128}$.

${ }^{123}$ Korzystało z tego tylko 9\% gospodarstw domowych. H. Strzemińska, op. cit., s. 198.

${ }^{124}$ Odpowiednie dane zostały zebrane przez GUS w ramach powszechnego badania dojazdów do pracy z 1 X $1964 \mathrm{r}$.

${ }_{125}$ D. Graniewska, Żłobki i przedszkola w PRL, Warszawa 1971, s. 34 i n.

${ }^{126}$ Młodzi po ślubie..., s. 219.

${ }^{127}$ H. Strzemińska, op. cit., s. 64-65. Brak opieki nad dziećmi ze strony pracujących rodziców traktowano jako główną przyczynę patologii społecznych wśród nieletnich. T. Rek, Przestepczość wśród młodocianych, „Prawo i Życie” 1957, nr 10.

${ }^{128}$ H. Strzemińska, op. cit., s. 21. 
W Polsce układ dnia był dla kobiet mniej korzystny. W społeczności toruńskiej działalność zawodowa, dojazdy do pracy i obowiązi domowe zajmowały w 1964 r. robotnicom ok. 15 godz., pracownicom handlu - ok. 13 godz., urzędniczkom - 12 godz. W ten sposób robotnice miały na życie rodzinne i rozrywki ok. 1 godz. (spały o ok. godzinę krócej niż pracownice umysłowe), zatrudnione w handlu - ok. 1 godz. i 30 min godz., a urzędniczki - ok. 2 godz. i 30 min. $^{129}$

Jak wykorzystywano tzw. czas wolny? Spory odsetek $(85,1 \%$ mężczyzn i $76,3 \%$ kobiet) sięgał po popularne gazety i tygodniki ${ }^{130}$. Czytelnictwo książek kształtowało się na poziomie $20-30 \%$, tyleż samo mieszkańców kraju unikało styczności ze słowem drukowanym ${ }^{131}$. Badania szczegółowe w różnych regionach kraju pokazywały, że ankietowani, niezależnie od zawodu i poziomu wykształcenia, najchętniej odpoczywali przy radioodbiorniku, z gazeta na podorędziu. Również spotkania towarzyskie ze znajomymi i rodzina odbywały się w znacznej mierze w domu. Uprawianie sportu należało do rzadkości (nie więcej niż $5 \%$ przepytywanych), zastępowano je spacerami, toteż w niedzielę „po kościele” skwery i parki wypełniały się odświętnie ubranym tłumem ${ }^{132}$.

Miejscem tłumnie odwiedzanym były również kina. Liczba sal projekcyjnych systematycznie rosła, poprawiał się ponadto ich stan techniczny ${ }^{133}$. Na zainteresowanie X muzą wpłynęły w poważnej mierze międzynarodowe sukcesy filmu polskiego na przełomie lat pięćdziesiątych i sześćdziesiątych, a także nowa polityka repertuarowa, w ramach której na ekranach pojawiły się $\mathrm{w}$ nieporównywalnie większym niż w czasach stalinowskich zakresie dzieła kinematografii „zachodniej”"134. Toteż nawet ci z ankietowanych, którzy skarżyli się na brak czasu, na niemożność znalezienia opiekunki do dziecka itp., odwiedzali z mniejszą lub większą regularnością sale kinowe.

Czasy, w których główną instytucją kulturalną staje się telewizor, miały przyjść dopiero w następnej dekadzie. W latach sześćdziesiątych przeszkodę

${ }^{129}$ Ibidem, s. 61. Trzeba mieć przy tym na uwadze, że część przedsiębiorstw w Polsce pracowała w systemie trójzmianowym. W PRL-u obowiązywała ustawa z 2 VII 1924 r. wprowadzająca zakaz pracy nocnej dla kobiet ciężarnych (począwszy od czwartego miesiąca ciąży) oraz posiadających dzieci poniżej roku życia. Pracę nocną kobiet limitowały również układy zbiorowe. Badania prowadzone w Europie w latach sześćdziesiątych pokazywały szkodliwość takiej pracy dla zdrowia pracujacych.

130 „Życie Warszawy”, „Ekspres Wieczorny”, „Kulisy”, „Kobieta i Życie”, „Przyjaciółka”.

131 B. Łobodzińska, Rodzina w Polsce..., s. 102.

${ }^{132}$ H. Strzemińska, op. cit., s. 106.

${ }^{133}$ W 1960 r. było w kraju 3090 kin stałych (w tym 1627 na wsi), w 1964 r. - 3511 (na wsi 1983). W omawianym czasie utrzymywała się wciąż instytucja kin objazdowych.

${ }^{134}$ W 1960 r. odbyło się 225 premier filmowych (z czego 208 filmów importowanych), w 1964 r. - 196 (182). Natomiast liczba widzów spadła z $201 \mathrm{mln}$ w 1960 r. (w tym 33 mln na wsi) do $177 \mathrm{mln}$ w $1964 \mathrm{r}$. (w tym $35 \mathrm{mln}$ na wsi). Warszawa (1,1 mln mieszkańców) posiadała w 1960 r. 48 kin, 23 teatry i filharmonie, 19 muzeów. Sieć ta była skromniejsza niż w Pradze, Bukareszcie, Budapeszcie i Moskwie, nieco bogatsza niż w Sofii i Belgradzie. 
stanowiły względy techniczne. W całym kraju zarejestrowanych było w $1960 \mathrm{r}$. 3,7 mln słuchaczy posiadajacych własne odbiorniki radiowe (z czego na wsi 1,1 mln), ale tylko 426 tys. abonentów telewizji (w tym 58 tys. na wsi) ${ }^{135}$.

Materiały zgromadzone przez dziennikarzy pozwalaja przypuszczać, że trudne często warunki życia mogły dezorganizować funkcjonowanie rodzin, prowadzić do rozczarowań, indywidualnych dramatów itp. Natomiast w wymiarze statystycznym małżeństwo okazywało się instytucją dość trwałą. W latach 1957-1960 liczba wniosków rozwodowych wzrosła z 30,7 tys. do 31,5 tys., lecz liczba orzeczonych rozwodów spadła z 15,6 tys. do 14,8 tys. (5 na 10 tys. ludności) ${ }^{136}$.

Rozwody dotykały przede wszystkim ludność dużych miast (Warszawa, Łódź, Kraków, Poznań, Wrocław), jak też województw najbardziej zurbanizowanych (katowickie, gdańskie, szczecińskie, zielonogórskie i koszalińskie). Wskaźnik rozwodów (1 na 10 tys. ludności) w miastach w latach 1957-1960 nieznacznie malał (od 10,4 do 8,8 na 10 tys. ludności), by następnie wstapić na ścieżkę wzrostu (13,0 w 1966 r.), natomiast na wsi zmieniał się tylko nieznacznie (1,5 w 1960 r., 2,4 w 1966 r.). W tym ostatnim obszarze rozwody zdarzały się głównie w rodzinach tzw. chłoporobotników, jak też pracowników PGR-ów ${ }^{137}$.

Polacy na początku dekady lat sześćdziesiątych rozwodzili się podobnie jak Belgowie i Holendrzy, zdecydowanie częściej niż Irlandczycy i Portugalczycy, wyraźnie rzadziej niż Austriacy, Duńczycy, Rumunii, Szwedzi i Węgrzy oraz mieszkańcy Czechosłowacji, Jugosławii i NRD.

Statystyka rozwodowa uwiarygodniała głosy tych wszystkich, którzy przestrzegali przed wstępowaniem na ścieżki małżeńskie w bardzo młodym wieku. Wśród decydujacych się na rozwód (w 1960 r.) 50\% mężczyzn i 69\% kobiet wzięło ślub przed 25. rokiem życia. Statystyczny margines (poniżej 6\%) stanowili rozwodnicy, którzy wzięli ślub w wieku 35-39 lat albo później. Najczęściej rozpadały się małżeństwa trwające od 5 do 9 lat, a od $1960 \mathrm{r}$. rósł też odsetek rozwodów wśród par ze stażem małżeńskim od 10 do 14 lat. Średni wiek rozwodzącego się mężczyzny wynosił 37 lat, a kobiety - ok. 34 lat. Rzadko kiedy rozwodziły się pary, w których istniała spora różnica wieku (powyżej 5 lat) między małżonkami ${ }^{138}$.

135 Część odbiorców korzystała z głośników podłączonych do lokalnego radiowęzła. W Warszawie zarejestrowano 338 tys. radioabonentów (299 na 1000 ludności) i 72 tys. teleabonentów (63 na 1000 ludności). Pod względem liczby abonentów radia i telewizji Warszawa wypadała lepiej niż inne stolice państw bloku sowieckiego. Warszawa na tle dużych miast..., s. 26-27.

${ }^{136}$ Po 1960 r. liczba wniesionych spraw, jak też odsetek orzeczonych rozwodów rosły - w 1966 r. złożono 42,6 tys. wniosków, z czego 57,2\% zakończyło się rozwodem. Rozwody w latach 1949-1966, Warszawa 1968, s. 7. Statystyka ta nie obejmuje przypadków małżeństw, które się rozpadły, lecz nie zostały prawnie rozwiązane.

${ }^{137}$ W 1960 r. wskaźnik rozwodów w miastach wynosił 8,8 na 10 tys. ludności, ale w miastach powyżej 100 tys. mieszkańców - 11,7. Rozwody..., s. 10.

138 Ibidem, s. 18 i n. 
Zgodnie z ustawą ze stycznia $1946 \mathrm{r}$. sąd godził się na rozwód w wypadku stwierdzenia „stałego rozkładu życia małżeńskiego" ${ }^{139}$. Nie zadowalał się on przy tym złożonymi przez strony wyjaśnieniami, bo przeważnie każda z nich przedstawiała sytuację w sposób dla siebie korzystny ${ }^{140}$. Stąd pojawiające się opinie, że proces sądowy nie pozwala na ustalenie rzeczywistych przyczyn kryzysu małżeństwa. Małżonkowie skrywaja przecież różne tajemnice, a ponadto duża część wyroków zapadała bez orzeczenia o winie (w 1966 r. ok. 61\%) ${ }^{141}$.

Chociaż GUS był świadomy tego rodzaju mankamentów, to przeprowadził jednak w 1967 r., wspólnie z Ministerstwem Sprawiedliwości, badania w materii rozpadu małżeństw ${ }^{142}$. Ankietę wypełnili wszakże nie rozwodnicy, lecz sędziowie, którzy wpisali do odpowiednich rubryk informacje pochodzace z pozwów i przebiegu rozpraw. Niezależnie od grzechu niesprawdzalności i subiektywizmu, materiał ten pozwalał dostrzec czynniki cementujace albo dezintegrujące rodzinę. Podobnie jak we wcześniejszych ustaleniach ${ }^{143}$, tak i tym razem okazywało się, że do wystapienia o rozwód skłaniała najczęściej zdrada partnera $(30,6 \%)$. Na drugim miejscu $(23,2 \%)$ pozostawał alkoholizm, przeważnie jednak wymieniany łącznie z innymi zarzutami pod adresem współmałżonka ${ }^{144}$.

Powyższa prezentacja funkcjonowania „statystycznej” rodziny ma charakter niepełny, bo wzgląd na objętość tekstu spowodował pominięcie wielu istotnych wątków. Zamiast podsumowania można przytoczyć słowa Stefana Kisielewskiego, który wychwytując paradoksy nadwiślańskiego socjalizmu, zauważał, że:

w państwie posiadającym imponujący przemysł stoczniowy, olbrzymie huty i kopalnie, rozbudowującą się wciąż nowoczesną chemię i tak dalej, problemem nie do rozwiązania

${ }^{139}$ Rozkład ten mógł nastapić m.in. wskutek cudzołóstwa, odmawiania środków na utrzymanie rodziny, dopuszczenia się hańbiącego przestępstwa, nałogu pijaństwa lub narkomanii, a także choroby psychicznej lub niemocy seksualnej przed ukończeniem 50. roku życia. Do 1958 r. sprawy rozwodowe znajdowały się w gestii sądów wojewódzkich, od 1959 r. przeszły do kompetencji sądów powiatowych, lecz listę podmiotów uprawnionych do orzekania w tych sprawach sporządzał minister sprawiedliwości.

${ }^{140} \mathrm{~W}$ małżeństwach trwajacych do 14 lat powództwo rozwodowe wnosiły w 60\% kobiety, w wypadku związków o dłuższym stażu - w ok. $60 \%$ mężczyźni.

${ }^{141}$ Rozwody..., s. 25.

${ }^{142}$ Przyczyny rozwodów. Wyniki badania ankietowego przyczyn rozkładu matżeństw, przeprowadzonego $w$ listopadzie $1967 \mathrm{r}$., Warszawa 1968. Badaniom poddano 2 tys. spraw.

${ }^{143}$ W 1961 r. w Sądzie Wojewódzkim w Warszawie dokonano analizy kilkuset akt rozwodowych, z której wynikało, że przyczyną trwałego kryzysu była w 50\% zdrada, a w 10\% - alkoholizm.

${ }^{144} \mathrm{~W}$ ramach wzajemnych pretensji skłócone strony powoływały się też na niezgodność charakterów $(16,9 \%)$, niedobór seksualny $(4,8 \%)$ oraz niegospodarność i niezgodę w sprawach finansowych (4,5\%). Przyczyny rozwodów..., s. 34-35. W latach sześćdziesiątych rozwody pozostawały jeszcze zjawiskiem względnie marginalnym, niemniej już wówczas rodził się coraz ważniejszy z czasem problem społeczny, jako że część rozwiedzionych mężczyzn skutecznie unikała płacenia alimentów. 
jest zjedzenie czegoś na mieście, zatelefonowanie, złapanie taksówki, naprawa zamka we drzwiach. [...] Przez milionową stolicę iść możesz godzinę nie spotkawszy ani jednego czynnego automatu telefonicznego (przysięgam!), zaś tysiące wsi nie posiadają w ogóle połączeń telefonicznych i w razie pożaru zdane są na własne siły ${ }^{145}$.

Z wyłaniającego się ze statystyki obrazu widać, jak wielkim ciężarem dla sytuacji społeczno-ekonomicznej było brzemię niedorozwoju pochodzące z przeszłości. Początek lat sześćdziesiątych nie stanowił wprawdzie okresu marazmu i zastoju, lecz zmiany w sferze gospodarki i warunków życia wówczas zachodziły bardzo powoli. Sprawy te wymagają dalszych badań dotyczących zarówno nastrojów i zachowań społeczeństwa, jak i działań obozu władzy.

\section{Streszczenie}

Podstawą źródłową artykułu są materiały Głównego Urzędu Statystycznego, wyniki badań ankietowych, prowadzonych w latach sześćdziesiątych przez socjologów, a także dokumentacja konkursów pamiętnikarskich rozpisywanych przez redakcje czasopism społeczno-kulturalnych. Na podstawie tej dokumentacji odtworzono m.in. społeczne wyobrażenia na temat instytucji małżeństwa, a także niektóre aspekty funkcjonowania instytucji rodziny, związane z sytuacją ekonomiczna, warunkami mieszkaniowymi, poszerzajacym się zakresem podejmowania przez kobiety pracy zawodowej i wynikającymi $\mathrm{z}$ tego problemami w sferze podziału domowych obowiązków. W artykule pokazano, że względy psychologiczne i uwarunkowania ekonomiczne wpływały na demograficzny profil rodziny, przynosząc m.in. zmniejszenie się współczynnika dzietności.

\section{Poland after the October '56. A statistical guide to family life}

The article is based on the source material of the Central Statistical Office of Poland, results of surveys conducted in the 1960s by sociologists, and the documents of memoirs' contents organised by editorial boards of socio-cultural periodicals. On the basis of this material it was made possible to reconstruct, among other things, social perceptions of marriage, together with some aspects of functioning of family, related to the economic situation, housing conditions, increasing scope of professional activity of women and resulting problems in the division of domestic and family responsibilities. The article reveals that psychological considerations together with economic conditions influenced a demographic profile of the family, resulting in, among others, the decreasing fertility rate.

\section{Bibliografia}

Fidelis M., Kobiety, komunizm i industrializacja w powojennej Polsce, tłum. M. Jaszczurowska, Warszawa 2015.

Jarska N., Kobiety $z$ marmuru, robotnice $w$ Polsce $w$ latach 1945-1960, Warszawa 2015. Jarosz D., Mieszkanie się należy... Studium z peerelowskich praktyk społecznych, Warszawa 2010 .

${ }^{145}$ Kisiel, Zostajemy w tyle? Głowq $w$ ścianę, „Tygodnik Powszechny” 1963, nr 36. 
Łobodzińska B., Młodość, miłość, matżenstwo, Warszawa 1975.

Madej K., Spótdzielczość mieszkaniowa. Wtadze PRL wobec niezależnej inicjatywy społecznej (1961-1965), Warszawa 2003.

Młodzi po ślubie, wybór i oprac. M. Parzyńska, J. Horodecka, Warszawa 1966.

Biogram: Andrzej Chojnowski - prof. dr hab., profesor emer. Uniwersytetu Warszawskiego. Autor prac z zakresu historii Polski w XX wieku (ostatnio: „Twórczość obca nam klasowo". Aparat represji wobec środowiska literackiego 1956-1990, red. nauk. A. Chojnowski, S. Ligarski, Warszawa 2009), historii Europy Wschodniej (ostatnio: A. Chojnowski, J.J. Bruski, Ukraina, Warszawa 2006) i historii Bliskiego Wschodu (ostatnio: A. Chojnowski, J. Tomaszewski, Izrael, Warszawa 2003). E-mail: andrzejchojnowski@icloud.com. 